\title{
ASSESSING CAUSATION IN BREAST IMPLANT LITIGATION: THE ROLE OF SCIENCE PANELS
}

\author{
LAURAl L. HoOPer, * JoE S. CeCIL, ** AND ThOMAS E. Willging****
}

\section{INTRODUCTION}

While the idea of court-appointed experts has been supported by individuals concerned with the courts' ability to assess scientific and technical evidence, ${ }^{1}$ it

This article is also available at http://www.law.duke.edu/journals/64LCPHooper.

* Senior Research Associate, Federal Judicial Center.

** Senior Research Associate, Federal Judicial Center.

*** Senior Research Associate, Federal Judicial Center.

This article is adapted from a more lengthy report prepared for the Court Administration and Case Management Committee of the Judicial Conference of the United States. In gathering information for this article, we are indebted to many individuals for their comments and suggestions on the courts' appointment of neutral experts in the silicone breast implant litigation. We are also grateful to Judge Robert E. Jones and Chief Judge Sam C. Pointer (Ret.), who presided over the formation of expert panels in Hall v. Baxter Healthcare, Corp., 947 F. Supp. 1387 (D. Or. 1996) and In re Silicone Gel Breast Implants Products Liability Litigation, 793 F. Supp. 1098 (J.P.M.L. 1992), respectively, as well as the participants in these two cases, including the technical advisors, selection panel members, science panel members, special counsel, and attorneys. Their insights enriched our report. We also acknowledge the indispensable assistance of Judge John Koeltl of the Southern District of New York who served as our liaison to the Court Administration and Case Management Committee on this project. Among the staff at the Federal Judicial Center, we thank Donna Stienstra for her comments on earlier draft reports and Kristina Gill for her research assistance. The views expressed are those of the authors and not necessarily those of the Federal Judicial Center.

1. See, e.g., CARnegie Comm. On ScIEnce, Tech., And Gov'T., Science And Technology IN Judicial DECISION MAKING 37 (1993); Bert Black et al., Science and the Law in the Wake of Daubert: A New Search for Scientific Knowledge, 72 TEX. L. REV. 715, 795-96 (1994) (suggesting court-appointed experts as a means of testing the evidentiary reliability of scientific evidence after Daubert); Dan L. Burk, When Scientists Act Like Lawyers: The Problem of Adversary Science, 33 JURIMETRICS J. 363 (1993); Joe S. Cecil \& Thomas E. Willging, Accepting Daubert's Invitation: Defining a Role for Court-Appointed Experts in Assessing Scientific Validity, 43 EMORY L.J. 995 (1994) (describing the results of surveys and interviews with federal judges regarding court-appointed experts); Si-Hung Choy, Judicial Education After Markman v. Westview Instruments, Inc.: The Use of CourtAppointed Experts, 47 UCLA L. REV. 1423 (2000); Ellen E. Deason, Court-Appointed Expert Witnesses: Scientific Positivism Meets Bias and Deference, 77 OR. L. REV. 59 (1998); E. Donald Elliott, Toward Incentive-Based Procedure: Three Approaches for Regulating Scientific Evidence, 69 B.U. L. REV. 487, 507-11 (1989); Howard M. Erichson, Mass Tort Litigation and Inquisitorial Justice, 87 GEO. L.J. 1983 (1999) (urging the use of court-appointed experts in mass tort litigation); Samuel R. Gross, Expert Evidence, 1991 WIS. L. REV. 1113 (suggesting court-appointed experts as a solution to the problems that arise with testimony by parties' experts); Pamela Louise Johnston, Court-Appointed Scientific Expert Witnesses: Unfettering Expertise, 2 HIGH TECH. L.J. 249 (1988); John H. Langbein, The German Advantage in Civil Procedure, 52 U. CHI. L. REV. 823, 858-66 (1985) (suggesting that the growing managerial responsibilities in the role of a federal judge will lead to increases in the use of court-appointed experts); Carl B. Rubin \& Laura Ringenbach, The Use of Court Experts in Asbestos Litigation, 137 F.R.D. 35 (1991) (reporting on the use of court-appointed medical experts in asbestos); Jane F. Thorpe et al., Court-Appointed Experts and Technical Advisors, LITIG., Summer 2000, at 31; 
has often been resisted by attorneys and judges who confront such evidence. ${ }^{2}$ An increasing number of recent cases, however, suggest that court-appointed experts are gaining acceptance, even though appointments remain rare. ${ }^{3}$ Such growing acceptance may be due to the increasingly difficult nature of scientific and technical evidence, ${ }^{4}$ or to Justice Stephen G. Breyer's recent endorsement of such experts in General Electric Co. v. Joiner. ${ }^{5}$ Moreover, recent programs to aid judges in locating qualified experts who are willing to serve will likely encourage further appointments. ${ }^{6}$

Nevertheless, the appointment of such experts remains sufficiently rare that problems are difficult to anticipate. In two recent cases-Hall v. Baxter Healthcare Corp. ${ }^{7}$ and In re Silicone Gel Breast Implants Products Liability Litigation $^{8}$ - federal judges appointed panels of scientific experts to help assess con-

Tahirih V. Lee, Note, Court-Appointed Experts and Judicial Reluctance: A Proposal to Amend Rule 706 of the Federal Rules of Evidence, 6 YALE L. \& POL'Y REV. 480, 494-503 (1988).

2. See Cecil \& Willging, supra note 1, at 1018-19 (recounting judges' reasons for reluctance in appointing an expert); Ellen Relkin, Some Implications of Daubert and Its Potential for Misuse: Misapplication to Environmental Tort Cases and Abuse of Rule 706(a) Court-Appointed Experts, 15 CARDOZO L. REV. 2255 (1994).

3. See, e.g., FED. R. EVID. 706 advisory committee's note ("[E]xperience indicates that actual appointment is a relatively infrequent occurrence."); 3 JACK B. WEINSTEIN \& MARGARET A. BERGER, WEINSTEIN's EVIDENCE II 706[01], at 706-13 (noting the "remarkably few cases in which federal judges have appointed experts"). A Westlaw search of federal cases for the term "court appointed expert" reveals a greater number of case citations for each of the years following the decision in Daubert v. Merrell Dow Pharmaceuticals, Inc., 509 U.S. 579 (1993), than in any of the preceding 10 years. Prior to Daubert, the number of citations ranged from 17 to 43 per year; after Daubert, the range is from 48 to 72 case citations, with a gentle upward trend. For estimates of the incidence of appointment of experts by federal judges, see Cecil \& Willging, supra note 1, at 1004-07. For estimates of the incidence of appointment under a broad range of authority to serve in managerial as well as testifying roles, see Ellen E. Deason, Managing the Managerial Expert, 1998 U. ILL. L. REV. 341, 347 n.19. For estimates of the incidence of appointment by state court judges, see Anthony Champagne et al., The Problem with Empirical Examination of the Use of Court-Appointed Experts: A Report of Non-Findings, 14 BEHAV. SCI. \& L. 361, 364 (1996); Daniel W. Shuman et al., An Empirical Examination of the Use of Expert Witnesses in the Courts-Part II: A Three City Study, 34 JURIMETRICS J. 193, 204 (1994).

4. See Federal Courts Study Comm., Report of the Federal Courts Study COMMITTEE 97 (1990) ("Economic, statistical, technological, and natural and social scientific data are becoming increasingly important in both routine and complex litigation."); see also Erichson, supra note 1, at 1986 (noting that trends in mass tort litigation suggest greater use of "inquisitorial tools" within the adversarial system); Relkin, supra note 2, at 2255 n.4 (suggesting that Rule 706 experts will become more common following Daubert).

5. 522 U.S. 136, 149-50 (1997) (Breyer, J., concurring) (urging judges to appoint scientific experts to help courts fulfill their gatekeeping function under Daubert); see also Daubert, 509 U.S. at 595 (listing the appointment of experts under Rule 706 among the procedures that judges should consider when confronted with difficult scientific evidence).

6. The American Association for the Advancement of Science ("AAAS") has developed a pilot project to provide federal judges with candidates recruited from science and professional organizations willing to serve as court-appointed experts. See Court Appointed Scientific Experts: A Demonstration Project of the $A A A S$ (visited Jan. 29, 2001) <http://www.aaas.org/spp/case/case.htm>. The Private Adjudication Center at Duke University has established a registry of independent scientific and technical experts who are willing to provide advice to courts or serve as court-appointed experts. See Registry of Independent Scientific and Technical Advisors (visited Jan. 29, 2001) $<\mathrm{http} / / /$ www.law.duke.edu/ pac/registry/index.html $>$.

7. 947 F. Supp. 1387 (D. Or. 1996).

8. 793 F. Supp. 1098 (J.P.M.L. 1992). 
flicting scientific testimony regarding causation of systemic injuries by silicone gel breast implants. This article will describe the circumstances that gave rise to the appointments, the procedures followed in making the appointments and reporting to the courts, and the reactions of the participants in the proceedings. It will also offer specific suggestions for improving the use of such panels of appointed science experts. Expert panels may be developed and used in a variety of ways; these approaches illustrate only two forms that such panels may take.

Part II offers a brief overview of the silicone gel breast implant product liability litigation and the two cases in which science panels were appointed. Subsequent parts compare the procedures used to select the experts, the instruction of the expert panels in their tasks, the preparation of the panels' reports, the depositions and testimony of the panel members, and the costs of the two programs. Part VIII provides a preliminary assessment of the effect of each program based on the participants' impressions and citations to the reports in related litigation. Finally, Part IX summarizes participants' overall reactions to the two procedures and suggests issues for judges to consider when appointing future panels.

\section{II}

\section{OVERVIEW OF SILCONE GEL BREAST IMPLANT LITIGATION}

Claims of systemic injuries arising from silicone gel breast implants have presented some of the most complex scientific evidence issues in the federal courts. ${ }^{10}$ Following the removal of silicone gel breast implants from the market

9. Our approach in gathering information differed for the two programs. Because the experts in the Oregon program delivered their reports before we began the study, our analysis was based on interviews in which participants recounted events that had, in some instances, occurred months in the past. The participants were aware of Judge Jones' ruling in the case, and it may have influenced their assessment of the procedure. Most interviews were conducted in person during a three-day visit to the court. Interviews with the attorneys took place at a conference that Judge Jones convened in his chambers upon our arrival. The multidistrict litigation program in Judge Pointer's court, on the other hand, was in its early stages when we began our study; therefore, we were able, over a two-year period, to attend a number of hearings and to have ongoing discussions with some participants regarding the development of the program. As a result, we have much more detailed information about the operation of Judge Pointer's program. Discussions with the members of the selection panel involved activities that had taken place before the beginning of the study. Interviews with experts, special counsel, and attorneys were delayed until the completion of the videotaped trial deposition of the appointed experts. Most of the formal interviews were conducted by telephone, and in most instances we promised the panel members that we would not attribute specific comments to any individual.

10. For an overview of litigation concerning silicone gel breast implants, see generally MARCIA Angell, Science On Trial: The Clash of Medical Evidence and the LaW in the Breast IMPLANT CASE (1996); MARY White STEWART, Silicone SPILls: BrEAST IMPLANTS ON TRIAL (1998). For commentary on the use of panels of appointed experts in silicone gel product liability litigation, see generally Erichson, supra note 1; Barbara S. Hulka et al., Experience of a Scientific Panel Formed to Advise the Federal Judiciary on Silicone Breast Implants, 342 NEW ENG. J. MED. 812 (2000); Karen Butler Reisinger, Court-Appointed Expert Panels: A Comparison of Two Models, 32 IND. L. REV. 225 (1998) (comparing the role of the expert panels in Hall and In re Silicone Breast Implants); James T. Rosenbaum, Lessons from Litigation over Silicone Breast Implants: A Call for Activism by Scientists, 276 SCIENCE 1524 (1997); Joseph Sanders \& David H. Kaye, Expert Advice on Silicone Implants: Hall v. Baxter Healthcare Corp., 37 JURIMETRICS J. 113 (1997); Thorpe et al., supra note 1, at 
in 1992 by the Food and Drug Administration, more than 400,000 cases were filed in federal and state courts alleging injuries arising from leakage or rupture of the shell that encased the silicone gel. The most troublesome allegation concerned the extent to which the silicone gel caused or exacerbated connective tissue diseases or immune system dysfunction. ${ }^{11}$ Research on these issues was being reported even as the cases were being litigated. ${ }^{12}$ Moreover, an assessment of this research required an understanding of several areas of science, including epidemiology, toxicology, immunology, rheumatology, chemistry, and statistics. The emerging nature of this research and differing research methodologies have made such cases among the most difficult ever presented in federal courts. ${ }^{13}$

The federal courts have responded to this wave of difficult cases by consolidating the cases for pretrial proceedings. In 1992, the Judicial Panel on Multidistrict Litigation transferred all silicone gel breast implant product liability cases filed in federal courts to the United States District Court for the Northern District of Alabama before Chief Judge Sam C. Pointer, Jr. ${ }^{14}$ As cases became ready for trial, Judge Pointer returned them to the districts of origin with the expectation that early trials would set benchmarks that could be used to encourage settlement negotiations. Among those early cases was a group of approximately seventy cases returned to the District of Oregon that gave rise to Hall v. Baxter Healthcare Corp.

The procedural circumstances that led to the appointment of the expert panel in the federal breast implant litigation are recounted more fully elsewhere and will not be repeated here. ${ }^{15}$ The following is a summary of the activities of

31; Laurens Walker \& John Monahan, Scientific Authority: The Breast Implant Litigation and Beyond, 86 VA. L. REV. 801 (2000).

11. Allegations of systemic injuries were only one of several claims raised by plaintiffs in this litigation. Plaintiffs typically alleged causes of action for "negligence, fraud and misrepresentation, strict liability, breach of express and implied warranties, violation of various consumer protection statutes and loss of consortium." In re Breast Implant Cases, 942 F. Supp. 958, 959 (E. \& S.D.N.Y. 1996). Plaintiffs also claimed a variety of "local injuries" including "capsular contracture, rupture, leakage, migration, granulomas, infection and temporary or permanent disfigurement." Id.; see also Sanders \& Kaye, supra note 10, at 117 ("Plaintiffs have claimed a variety of injuries due to implants. Some cases involve ruptured implants, and affected plaintiffs often seek compensation for pain, inflammation, and other local effects, as well as the expense of having the implant replaced or removed.").

12. See Institute of Med., SAFETy of Silicone Breast Implants 11 (Stuart Bonduant et al. eds., 2000) available at <http://books.nap.edu/books/0309065321/html /index.html> (visited Apr. 10, 2001) ("Evidence suggests that [connective tissue diseases, cancer, neurological diseases or other systematic complaints or conditions] are no more common in women with breast implants than in women without breast implants."); see also id. at 179-97, 215-32.

13. For a comparison of the findings by the Institute of Medicine study and the National Science Panel in the multidistrict litigation, see $i d$. at 505-14 app. C.

14. The multiple attempts to develop settlement agreements are recounted in Erichson, supra note 1, at 1991 (noting that the expert panel's report of the panel "appears to have been a driving force" in settling the Dow Corning bankruptcy agreement); and Walker \& Monahan, supra note 10, at 805-07.

15. For a summary of the procedural posture of the litigation when the expert panels were appointed, see Laural L. HoOper et Al., Neutral SCIENCE PANEls: Two EXAMPles OF Panels OF COURT-APPOINTED EXPERTS IN THE BREAST IMPLANTS PRODUCT LIABILITY LITIGATION 7-8, 13-15 (2000) [hereinafter FJC STUDY]. For Judge Pointer's orders concerning the National Science Panel, see, e.g., Order No. 31, Appointment of Rule 706 Expert Witnesses, In re Silicone Gel Breast 
the expert panels in Hall and the multidistrict litigation; a more detailed account is set forth in the sections that follow. Our analysis of the activities of the two expert panels will stress the difference in the roles that they were asked to play in the litigation.

In Hall, Judge Jones used the expert panel to help resolve twenty-five joint motions in limine that sought to exclude the testimony of plaintiffs' expert witnesses in cases consolidated for trial. ${ }^{16}$ Although the experts were appointed as "technical advisors" under the inherent authority of the court, ${ }^{17}$ Judge Jones agreed to a number of procedural protections required when experts are appointed under Rule $706 .^{18}$ Because he was considering the admissibility of challenged evidence, Judge Jones framed his instructions to the panel of experts around the Daubert standards at the time. ${ }^{19}$ Approximately four months after their appointment, the experts submitted individual reports, in general suggesting that the scientific evidence, which showed that silicone gel breast implants cause disease, is unreliable. ${ }^{20}$ The parties shared the fees of the panel. ${ }^{21}$

In comparison, in the multidistrict litigation, Judge Pointer used the expert panel as court-appointed experts under Rule 706 to develop videotaped testimony on various scientific issues with the intention of having that testimony become part of the record when the cases were returned to the local district courts. Judge Pointer's decision to appoint this panel was, in part, a response to the actions of Judge Jones and other federal judges who were planning to ap-

Implants Prods. Liab. Litig. (MDL 926), 793 F. Supp. 1098 (J.P.M.L. 1992) (No. CV92-P-10000-S) (visited Jan. 29, 2001) <http://earth.fjc.gov/ BREIMLIT/ORDERS/order31.rtf>; Order No. 31B, Confirming Order No. 31, Silicone Gel Breast Implants (No. CV92-P-10000-S) (visited Jan. 29, 2001) $<$ http://earth.fjc.gov/BREIMLIT/ORDERS/order31b.rtf>; Order No. 31E, Directions to National Science Panel under FRE 706, Silicone Gel Breast Implants (No. CV92-P-10000-S) (visited Jan. 29, $2001)<$ http://earth.fjc.gov/BREIMLIT/ORDERS/order31e.rtf $>$. For the Report of National Science Panel, see National Science Panel, Silicone Breast Implants in Relation to Connective Tissue Diseases and Immunologic Dysfunction (Nov. 17, 1998) (visited Feb. 21, 2001) < http://earth.fjc.gov/BREIMLIT/ SCIENCE/report.htm>.

16. See Hall v. Baxter Healthcare Corp., 947 F. Supp. 1387, 1392 n.7 (D. Or. 1996).

17. See Ex parte Peterson, 253 U.S. 300, 312 (1920) (holding that a federal court has the inherent authority "to appoint persons unconnected with the court to aid judges in the performance of specific judicial duties"); Reilly v. United States, 863 F.2d 149, 154-55, 159-60 (1st Cir. 1988).

18. Consistent with the procedural safeguards of Rule 706(a), Judge Jones agreed to provide a written charge to the technical advisors, to communicate with the advisors on the record, and to allow the attorneys a limited opportunity to question the advisors regarding the content of their reports. See FJC STUDY, supra note 15 , at 9.

19. See Hall, 947 F. Supp. at 1393-94 (listing the questions posed to the panel members).

20. Three of the technical advisors found little scientific support for the contentions of the plaintiffs' experts. Specifically, the court's immunologist stated that the plaintiffs' experts' position was neither well-supported by the data available in the published scientific literature nor derived from valid conclusions of the studies. See id. at 1461. Similarly, the rheumatologist criticized plaintiffs' experts for using scientifically invalid methodology. See id. at 1452. The biochemist concluded that the chemical studies were based on appropriate methods but that some of the "work was inadequately documented and of clearly debatable value." Id. at 1475-76. The epidemiologist generally thought that the plaintiffs' epidemiologists' opinions were supported by scientific reasoning and methodology generally used in the field of epidemiology. See id. at 1450-51. Judge Jones, however, excluded the epidemiological testimony on other grounds, finding plaintiffs' two experts' testimony to be unreliable. See id. at $1405-07$.

21. See id. at 1393 n.9. 
point expert panels in cases returned from the multidistrict litigation process. ${ }^{22}$ Before these expert panels were assembled, the national Plaintiffs' Steering Committee ("PSC"), apparently motivated by concerns that local appointments of experts by national defense attorneys could proliferate and possibly overwhelm the resources of local plaintiffs' attorneys, urged Judge Pointer to consider appointing a national panel of experts. ${ }^{23}$ Defendants opposed the PSC initiatives to create a national panel primarily on jurisdictional grounds. ${ }^{24}$ In May 1996, Judge Pointer appointed a panel of special masters to commence the process of screening individuals to serve as members of the National Science Panel. ${ }^{25}$ Based on their recommendations, Judge Pointer appointed three panel members in August and a fourth member in September 1996. ${ }^{26}$ In November 1998, the panel members produced a report indicating a lack of reliable scientific evidence to establish an association between breast implants and any of the connective tissue diseases or the other autoimmune or rheumatic conditions. ${ }^{27}$ In February 1999, Judge Pointer presided over discovery depositions of the four panel members. ${ }^{28}$ In April 1999, the panel members presented eight days of

22. In addition to Judge Jones' plans to appoint a panel of experts, Judge Jack Weinstein of the Eastern District of New York and Judge Harold Baer of the Southern District of New York developed a plan for appointing a joint panel of experts to serve in breast implant litigation consolidated for trial in those two districts. See Joint Order No. 1, Appointment of Special Masters, In re Silicone Gel Breast Implant Prods. Liab. Litig., No. 96-BI-1 (E.D.N.Y. 1996) and No. 91-CV-6996 (S.D.N.Y. Apr. 3, 1996); see also Barry Meier, Judges Set Up Review Panel for Lawsuits on Implants, N.Y. TIMES, Apr. 4, 1996, at A14.

23. See FJC STUDY, supra note 15 , at 14.

24. See id. at 14-15.

25. See Order No. 31, Appointment of Rule 706 Expert Witnesses, In re Silicone Gel Breast Implants Prods. Liab. Litig. (MDL 926), 793 F. Supp. 1098 (J.P.M.L. 1992) (No. CV92-P-10000-S) (visited Jan. 29, 2001) <http://earth.fjc.gov/BREIMLIT/ORDERS/order31.rtf>.

26. See Order No. 31C, Appointing Members of National Science Panel, Silicone Gel Breast Implants (No. CV92-P-10000-S) (visited Jan. 29, 2001) <http://earth.fjc.gov/BREIMLIT/ORDERS/ order31c.rtf>; Order No. 31D, Appointing Additional Member of National Science Panel and Precluding Ex Parte Communications with Panel Members, Silicone Gel Breast Implants (No. CV92-P10000-S), (visited Jan. 29, 2001) <http://earth.fjc.gov/BREIMLIT/ ORDERS/order31d.rtf>. Judge Pointer also appointed a private attorney as special counsel to the national panel of experts and directed that any communication between the special counsel and the panel members be covered by the attorney-client privilege. See Order No. 31F, Appointment of Special Counsel to National Science Panel, Silicone Gel Breast Implants (No. CV92-P-10000-S) (visited Jan. 29, 2001) <http:// earth.fjc.gov/BREIMLIT/ ORDERS/order31f.rtf>. Sometime thereafter, a second special counsel was appointed to help prepare panel members for trial dispositions.

27. See National Science Panel, supra note 15. The Panel found that the presence of silicone gel breast implants "do[es] not alter incidence or severity of autoimmune disease" and that women with implants "do[] not display a silicone-induced systemic abnormality in the ... cells of the immune system." Id. National Science Panel, Silicone Breast Implants in Relation to Connective Tissue Diseases and Immunologic Dysfunction, Executive Summary at 5-6 (visited Jan. 29, 2001) $<$ http://earth.fjc.gov/ BREIMLIT/ SCIENCE/summary.rtf>. In addition, the Panel found that "[n]o association was evident between breast implants and any of the . . connective tissue diseases ... or the other autoimmune/rheumatic conditions" and no association was evident between implants and "undifferentiated connective tissue disease." Id. at 6-7.

28. See Order No. 31J, Supplemental Instructions Regarding Discovery Depositions, Silicone Gel Breast Implants (No. CV92-P-10000-S) (visited Jan. 29, 2001) <http://earth.fjc.gov/BREIMLIT /ORDERS/order31j.rtf>. 
videotaped trial testimony. ${ }^{29}$ As of February 2001, the videotapes are still being edited. In the interim, all but a few of the cases have been settled, raising questions about whether the videotapes will ever be shown in a federal trial. Much of the cost of the expert panel was paid by the federal judiciary, with parties sharing the cost of the hearings and the special counsels. ${ }^{30}$

Table 1 summarizes the differences in the two panels of appointed experts. These differences are discussed at length in the sections below.

TABLE 1

SUMMARY COMPARISON OF THE TWO USES OF PANELS OF APPOINTED EXPERTS IN SILICONE GEL BREAST IMPLANT LITIGATION

\begin{tabular}{|c|c|c|}
\hline & $\begin{array}{l}\text { Hall v. Baxter Healthcare Corp. } \\
\text { (Judge Robert Jones, } \\
\text { D. Or.) }\end{array}$ & $\begin{array}{l}\text { In re Silicone Gel Breast } \\
\text { Implant Products Liability } \\
\text { Litigation, MDL-926 } \\
\text { (Judge Sam Pointer, Jr., N.D. } \\
\text { Ala.) }\end{array}$ \\
\hline Purpose of Appointment & $\begin{array}{l}\text { Aid a single district court in } \\
\text { resolving defendants' motions } \\
\text { in limine to exclude plaintiffs' } \\
\text { expert scientific testimony } \\
\text { in the context of cases } \\
\text { consolidated for trial }\end{array}$ & $\begin{array}{l}\text { Develop, as part of a multi- } \\
\text { district litigation proceeding, } \\
\text { testimony by court-appointed } \\
\text { experts regarding general } \\
\text { causation for presentation at } \\
\text { trial }\end{array}$ \\
\hline Authority for Appointment & $\begin{array}{l}\text { Appointed as technical advisors } \\
\text { under the authority of Federal } \\
\text { Rule of Evidence } 104 \text { and on } \\
\text { the inherent authority of the } \\
\text { court }\end{array}$ & $\begin{array}{l}\text { Appointed as court-appointed } \\
\text { experts under the authority of } \\
\text { Federal Rule of Evidence } 706\end{array}$ \\
\hline $\begin{array}{l}\text { Primary Product of Expert } \\
\text { Panel }\end{array}$ & $\begin{array}{l}\text { Individual expert reports that } \\
\text { informed the court as it } \\
\text { considered the motions in } \\
\text { limine }\end{array}$ & $\begin{array}{l}\text { Videotaped testimony of court- } \\
\text { appointed experts for } \\
\text { presentation at trial or at } \\
\text { preliminary hearings }\end{array}$ \\
\hline $\begin{array}{l}\text { Subsequent Use of Primary } \\
\text { Product }\end{array}$ & Uncertain & $\begin{array}{l}\text { Videotaped testimony intended } \\
\text { to become part of the record of } \\
\text { each case returned to the } \\
\text { transferor court }\end{array}$ \\
\hline $\begin{array}{l}\text { Number of Cases in the } \\
\text { Proceeding }\end{array}$ & $\approx 70$ & $\approx 27,000$ \\
\hline $\begin{array}{l}\text { Time from Start of Selection } \\
\text { to Completion of Duties of } \\
\text { Expert Panel }\end{array}$ & Approximately four months & Three years \\
\hline Source of Funding & Cost shared by the parties & $\begin{array}{l}\text { Judiciary appropriations with } \\
\text { party payment of discrete } \\
\text { components }\end{array}$ \\
\hline \multirow{2}{*}{$\begin{array}{l}\text { Total Cost of the Panel and } \\
\text { Related Expenses }\end{array}$} & \multirow[t]{2}{*}{$\approx \$ 76,000$} & $\approx \$ 1,000,000$ for the expert panel \\
\hline & & $\begin{array}{l}>\$ 1,000,000 \text { for special counsels } \\
\text { to represent the experts }\end{array}$ \\
\hline
\end{tabular}

29. See Order No. 31K, Protocol for Trial Perpetuation Depositions, Silicone Gel Breast Implants (No. CV92-P-10000-S) (visited Jan. 29, 2001) <http://earth.fjc.gov/BREIMLIT/ORDERS/order31k.rtf>.

30. See infra Part VIIB and note 193. 
III

\section{IDENTIFICATION AND SELECTION OF EXPERTS}

The difficulty in identifying and selecting appropriate individuals presents an initial barrier to the use of court-appointed experts and technical advisors. ${ }^{31}$ The problem of finding qualified candidates was compounded in each of the two cases considered here by the need for specialized experts in multiple areas of research. In identifying suitable candidates, both Judge Jones and Judge Pointer decided to seek the assistance of those with contacts in the science community. A number of unexpected problems arose during this process, which suggests that finding appropriate candidates may be more difficult than generally believed. For this reason, the identification and selection process is discussed in some detail.

\section{A. Hall v. Baxter Healthcare Corp.}

In May 1996, prior to a planned Rule 104(a) hearing, Judge Jones identified four relevant areas of scientific expertise to guide the appointment of experts: epidemiology, immunology, toxicology, rheumatology, and chemistry. ${ }^{32}$ He then appointed Dr. Richard Jones ${ }^{33}$ as a special master to help him identify scientists to serve as technical advisors. After examining the submissions of the parties to learn about the technical issues in dispute, ${ }^{34}$ Dr. Jones "sought the names of potential experts from senior faculty at the Oregon Health Sciences University in each specialty area" ${ }^{\prime 35}$ and from other professional scientific and academic colleagues. He then narrowed the initial pool of approximately seventy-five potential candidates to nine epidemiologists, two immunologists, fourteen rheumatologists, and six toxicologists, ${ }^{36}$ and contacted these potential candidates to

31. In general, federal judges tend to appoint experts with whom they are familiar: "[I]t is far more common for judges to appoint experts that they have identified and recruited, often based on previous personal or professional relationships, than for judges to appoint experts nominated by the parties." JoE S. CECIL \& ThOMAs E. Willging, Federal Judicial CTR., COURT-APPOINTED EXPERTS: DEFINING THE ROLE OF EXPERTS APPOINTEd UNDER FEDERAL RULE OF EVIDENCE 31 (1993).

32. See Hall v. Baxter Healthcare Corp., 947 F. Supp. 1387, 1392-93 (D. Or. 1996).

33. Dr. Richard Jones, M.D., Ph.D., is Professor Emeritus of the Department of Biochemistry and Molecular Biology at Oregon Health Sciences University, the former acting president of Oregon Health Sciences University, and the former chair of the University's biochemistry department. Judge Jones was aware of Dr. Jones's qualifications, in part, through their relationship as first cousins. A number of other interviewees confirmed that Dr. Jones is prominent in the biomedical research community and would be a likely resource for any judge who wished to identify local experts in certain areas of science.

34. "The court also instructed counsel to summarize each expert witness's opinion, to identify all the materials upon which each expert would rely for his or her opinions, and to submit transcripts of any testimony given by the witness in similar cases." Hall, 947 F. Supp. at 1392.

35. Richard T. Jones, M.D., Ph.D., Silicone Breast Implant Litigation: Process Used To Identify and Recommend Neutral Scientific Experts For Federal Rules of Evidence 104(a) Hearings Before the Honorable Robert E. Jones, U.S. District Court, District of Oregon 1 (Jan. 14, 1996) (unpublished manuscript, on file with authors).

36. See id. at 2. 
determine their level of interest and availability, as well as the existence of any bias or conflict. ${ }^{37}$

Public statements by many local rheumatologists regarding the breast implant litigation complicated the task of identifying a candidate who met the standards for neutrality. ${ }^{38}$ Dr. Jones filled the slot after obtaining recommendations from local rheumatologists for candidates outside the area.

Identifying a technical advisor with knowledge of immunology and toxicology was especially difficult. There are relatively few immunologists and toxicologists compared to other specialties, and many candidates had research and consulting relationships with defendant companies. The inability to identify a suitable toxicologist led Judge Jones to reconsider the nature of the expertise required on the panel. Because much of the toxicological evidence depended on the chemistry of silicone and its products, he determined that a biochemist would be able to meet this need.

At the conclusion of the screening process, Judge Jones appointed three technical advisors: Merwyn R. Greenlick ${ }^{39}$ for epidemiology, Robert F. Wilkens $^{40}$ for rheumatology, and Mary Stenzel-Poore ${ }^{41}$ for immunology and toxicology. After the evidentiary hearing, Judge Jones made one additional appointment: Ronald McClard ${ }^{42}$ for biochemistry. All four appointees were motivated primarily by the opportunity to provide a public service that might lead to improved use of scientific evidence in the legal system. In addition, two of the scientists had cited an intrinsic interest in the scientific issues to be studied regarding any possible causal relationship between silicone gel and systemic dis-

37. Throughout this article, the authors cite to information furnished to them in separate interviews with the participants in the study on the condition that their identities not be disclosed.

Screening for availability and bias was accomplished through telephone conversations. If a candidate expressed an interest and was available, Dr. Jones requested a "copy of [the candidate's] curriculum vitae and a statement indicating absence of any previous or current involvement with people or matters related to silicone breast implant litigation." Jones, supra note 35 , at 3 . One of the appointees, Dr. Merwyn R. Greenlick, had one previous experience with breast implants, in which he consulted on the design of an epidemiology study that was undertaken by persons in his academic department and funded jointly by both plaintiffs and defendants. This experience, however, was not deemed to be disqualifying.

38. See James T. Rosenbaum, Editorial, Silicone Dangers Mired in Ignorance, THE OREGONIAN, Mar. 27, 1996, at D7. Dr. Rosenbaum submitted an extensive list of co-authors for his article. As he explained:

The original draft of this letter was circulated to every identifiable rheumatologist in Oregon and southwest Washington. Eighty-four percent responded to the letter. Eighty-eight percent of respondents agreed completely with the contents, and an additional 12 percent agree with most of the sentiments. None of the respondents disagreed. Id.

39. Dr. Greenlick has a Ph.D. in Medical Care Organization and is a professor and chair of the Department of Public Health and Preventive Medicine at Oregon Health Sciences University.

40. Dr. Wilkins has an M.D. and is a specialist in immunology and toxicology from Seattle, Washington.

41. Dr. Stenzel-Poore has a Ph.D. in Immunology and is an assistant professor in the Department of Molecular Microbiology and Immunology at University of Oregon Health Sciences Center.

42. Dr. McClard has a Ph.D. in Biochemistry and is a professor of chemistry at Reed College. 
eases. The other two appointees cited their respect for Dr. Jones as a major factor in their decision.

\section{B. In re Silicone Gel Breast Implant Products Liability Litigation}

The selection panel used in the national breast implant litigation was initially developed by Judge Jack B. Weinstein for use in breast implant litigation in the Eastern and Southern Districts of New York. In April 1996, Judge Weinstein appointed Professors Margaret A. Berger, ${ }^{43}$ Joel E. Cohen, ${ }^{44}$ and Alan Wolf $^{45}$ as special masters to serve on the selection panel. ${ }^{46}$ In May 1996, after granting a motion by the PSC to appoint experts under Rule 706, Judge Pointer received Judge Weinstein's permission to adopt his procedure and selection panel as part of his multidistrict litigation process. ${ }^{47}$ Judge Pointer then added three additional members-Dr. Judith L. Craven, ${ }^{48}$ Dr. Richard Jones, ${ }^{49}$ and Dr. Keith Marton ${ }^{50}$ - to give the selection panel broader geographic representation and to aid in the identification of candidates with national reputations. ${ }^{51}$ After an initial in-person meeting of the first three appointees to discuss roles, procedures, and standards for evaluating candidates, all other communication was by telephone, electronic mail, conventional mail, and fax. The three panel members identified by Judge Pointer never met with the selection panel members appointed by Judge Weinstein or the nominees for inclusion on the science panel. Several selection panel members mentioned the lack of face-to-face meetings as an impediment to the efficient working of the selection panel. Like the experts appointed by Judge Jones in Oregon, the selection panel members were motivated primarily to serve by the public interest in having a courtappointed process in which judges and juries can obtain scientific information that informs their deliberations. In addition, almost all expressed an intrinsic interest in the scientific issues to be studied. One of the original panel members

43. Professor Berger, J.D., Columbia Law School, Professor of Law at Brooklyn Law School, is widely recognized as one of the nation's leading authorities on scientific evidentiary issues, in particular DNA evidence.

44. Professor Cohen is a well-known mathematician and scientist and head of the Laboratory of Populations at Rockefeller University.

45. Professor Wolf is a professor in the Department of Physics of the Cooper Union, and a graduate of and adjunct professor at the Benjamin N. Cardozo School of Law.

46. See Order No. 31 at 1 \& n.1, Appointment of Rule 706 Expert Witnesses, In re Silicone Gel Breast Implants Prods. Liab. Litig. (MDL 926) (No. CV92-P-10000-S) (visited Jan. 29, 2001) $<$ http://earth.fjc.gov/BREIMLIT/ORDERS/order31.rtf $>$.

47. See id. at 1.

48. Dr. Craven is a medical doctor and has a Master's degree in public health. She had recently served as dean of the University of Texas Health Science Center in Houston and was prominent in discussions of public policy regarding health care issues.

49. Dr. Richard Jones had recently served as a special master for U.S. District Judge Robert Jones in the Oregon breast implant litigation, as described above.

50. Dr. Kenneth Marton is a medical doctor, a fellow of the American College of Physicians, and has a background in epidemiology.

51. See Order No. 31, Appointment of Rule 706 Expert Witnesses, Silicone Gel Breast Implants (No. CV92-P-10000-S) (visited Jan. 29, 2001) <http://earth.fjc.gov/BREIMLIT/ORDERS/order31.rtf>. 
also cited respect for Judge Weinstein as an additional factor in his decision to serve.

1. Identifying Candidates for Appointment. At the initial meeting, the three selection panel members appointed by Judge Weinstein agreed that they would seek scientists with national reputations who had no significant ties to the litigation, no significant current or close past relationship with parties to the litigation, and no significant involvement in research likely to be introduced as evidence. After considerable discussion, the panel devised a conflict-of-interest form and required each expert to sign a copy before being appointed. ${ }^{52}$

After extensive discussions with Judge Pointer and input from the parties, the selection panel recommended that four fields be represented by the experts appointed to the science panel-epidemiology, toxicology, immunology, and rheumatology. ${ }^{53}$ As a minimum standard, they agreed to consider only those candidates who were actively conducting scientific research, thereby excluding most treating physicians. In addition, the selection panelists agreed that they preferred to nominate academic scholars, because the skeptical and independent perspective traditionally associated with academia was expected to be especially valuable in this inquiry. They also preferred scholars who had achieved the level of full professor to ensure that the experts consulted by the court were of equal stature with those consulted by the parties. In addition to scientific ex-

52. A copy of this form is appended to this article. After reviewing the claims of the parties, the selection panel members also agreed at this meeting on two standards regarding their own conduct. First, the selection panel agreed to be open in describing its activities, roles, and meetings, but cautious about attributing specific statements to identifiable individual scientists. Second, they agreed to hold themselves to a standard regarding conflicts of interest that is similar to that which they set for the scientists they reviewed. As a result, the members of the selection panel divested themselves and their immediate families of all financial interests in the approximately twenty or so corporations involved in the litigation-exclusive of any interests that arose from holdings in undifferentiated mutual fundsand paid capital gains taxes on the income from such sales. The selection panel also agreed that Professor Berger should field any press inquiries and speak on behalf of the group.

53. The selection panel also considered including experts in polymer chemistry, psychiatry, and oncology in their recommendations. The panel initially planned to recommend that a statistician be included on the panel, but the need for such expertise became less urgent in light of the statistical skills possessed by experts appointed. Judge Pointer's order appointing the selection panel notes that the science panel appointees are expected to have "such familiarity with statistics as may be needed or desirable to perform their functions and responsibilities." Order No. 31 at 4, Appointment of Rule 706 Expert Witnesses, Silicone Gel Breast Implants (No. CV92-P-10000-S) (visited Jan. 29, 2001) $<$ http://earth.fjc.gov/ BREIMLIT/ORDERS/order31.rtf $>$. At its initial meeting, one national science panel member inquired about regularly consulting with a statistical expert while reviewing existing studies. Judge Pointer left open the possibility of hiring a statistical consultant. The selection panel determined that an expert in polymer chemistry was unnecessary given the narrow issues that arise concerning polymer chemistry and the breadth of expertise in related areas on the science panel. It also determined that an expert in psychiatry was unnecessary in evaluating a causal relationship between exposure to silicone breast implant and organic disease. Judge Pointer's order permitted the selection panel to recommend "one or more persons with special expertise in the interrelationship between the forensic sciences and legal process and procedures, for appointment as Chair of the Science Panel" and to "perform administrative, coordinating, and consultative services." Id. at 3. The order did not, however compel the selection panel to "submit findings, be deposed, or present testimony." Id. The parties objected to the idea that a forensic specialist be appointed to chair the panel and address its administrative needs, and it was eventually abandoned. This void was later filled by the appointment of special counsel and, later, a second special counsel. 
cellence, the committee placed great weight on the ability of the candidate to communicate findings to a lay audience and the ability to work well in a committee setting. The screening panel also sought candidates who were openminded about whether there is a causal relationship between the silicone gel in breast implants and the systemic diseases raised in the litigation. Previous litigation experience, such as testifying as a party's expert in the breast implant litigation or serving on the panel in Oregon, weighed against a candidate because of the possible appearance of bias or prejudgment.

All six of the panel members used their professional and institutional contacts to identify candidates for the panel to consider. They also reviewed curriculum vitae, contacted professional references, and gathered other sources of information about candidates from public sources, including the Internet. The process of identifying candidates involved telephone conversations with hundreds of scientists over a six-month period. The panel sought input from scientists they knew personally and through contacts with professional organizations. A staff member of the National Academy of Sciences ("NAS") provided a valuable list of candidates from members of NAS committees and special study panels. Apart from that assistance, efforts to identify candidates by contacting professional societies and scientific organizations proved fruitless. ${ }^{54}$ Panel members also used computerized scientific reference services to identify researchers who were active in examining the general topics that arise in the litigation but who were not committed to a position on a disputed issue. In addition, they obtained information on the standing of candidates in the scientific community from their own networks of scientific and academic colleagues.

In general, personal relationships played an important role in the selection process. Members of the original panel had previous professional relationships with Judge Weinstein. ${ }^{55}$ All three additional members were referred to Judge Pointer by federal judges. Nominees for the science panel, in turn, were identified by pursuing networks so extensive that some finalists in the process were three or more steps removed from the selection panel person's initial contact.

54. The selection panel was wary of seeking nominations from those professional associations that had taken stands on issues that are the subject of dispute in the breast implant litigation. For example, the statement by the American College of Rheumatology that studies show no relationship between exposure to silicone implants and systemic disease made that entity inappropriate to nominate candidates for the science panel. The Selection Panel was also concerned that officers of a professional association might not be currently active in scientific research.

55. Prior to the appointments, Judge Weinstein had worked professionally with each member of the panel. He had collaborated with Professor Berger over the years on a variety of professional activities, including a well-known treatise on the law of evidence, and had also designated Professor Berger as a court-appointed expert in the Johns Manville bankruptcy reorganization proceedings. For a discussion of that appointment, see In re Joint Eastern and Southern District Asbestos Litig., 129 B.R. 710, 763-64 (E.D.N.Y. 1991). Among other duties, he asked her to identify scientists to serve on a separate panel of court-appointed experts that developed forecasts of the volume, type, and timing of future claims from asbestos-related injuries. Professor Cohen also participated in the Johns Manville bankruptcy reorganization. Judge Weinstein selected him to serve on the expert panel that prepared forecasts of future asbestos claimants. Professor Wolf had served as a student intern for Judge Weinstein while in law school. Following his internship, Professor Wolf served as an expert for a private party in the Johns Manville bankruptcy reorganization. 
Personal relationships also played an important role in assessing the scientific reputations and collegiality of prospective nominees. Selection panel members asked those who were likely to know a candidate about his or her professional standing and temperament.

2. Screening for Conflicts of Interest. Once a promising candidate was identified and had indicated an interest in serving, he or she was asked to submit information required of testifying experts under Federal Rule of Civil Procedure 26(a)(2)(B). ${ }^{56}$ Selection panelists made telephone calls to others in the field to learn of the candidate's reputation for scientific rigor and objectivity. Extensive searches of Internet and electronic databases were used to identify publications, professional affiliations, public controversies in which the candidate had participated, and litigation in which the candidate may have served as an expert. Databases of publicly available information regarding property and financial assets were also examined for potential conflicts. While the members of the selection panel were uneasy about inquiring into such matters, they knew that counsel for the parties would conduct similar investigations of science panel appointees. Over 100 hours were spent conducting electronic network searches for information about potential candidates.

The most difficult part of the screening process was identifying candidates who met the panel's exacting tests for impartiality and did not have conflicts of interest. When we asked later about the conflicts screening, those panel members who were selected to serve said they did not object to it. To screen candidates for conflicts, the selection panel used a form modeled on one used by the NAS. ${ }^{57}$ The form proved to be a crucial part of the screening process. It asked the candidate to certify that the candidate and those with a close relationship to the candidate did not fall within the definition of an "interested party." "interested party" was defined broadly to include factors such as (1) having a stake in the outcome of the litigation; (2) having the potential to be a litigant in this case; (3) having close friends or attorneys involved in the litigation; (4) having a financial interest in one or more corporate defendants; (5) having a family member or friend working for a party; (6) conducting prior research on breast implants; (7) receiving funding for research from one of the parties; (8) making public statements regarding the disputed issues; (9) working as an ex-

56. Federal Rule of Civil Procedure 26 (a)(2)(B) provides:

[A] disclosure shall... be accompanied by a written report prepared and signed by the witness. The report shall contain a complete statement of all opinions to be expressed and the basis and the reasons therefor; the data or other information considered by the witness in forming the opinions; any exhibits to be used as a summary of or support for the opinions; the qualifications of the witness, including a list of all publications authored by the witness within the preceding ten years; the compensation to be paid for the study and testimony; and a listing of any other cases in which the witness has testified as an expert at trial or by deposition within the preceding four years.

57. See infra Appendix: Conflict and Bias Screening Questionnaire.

58. See id. 
pert with any party or attorney for any party; or (10) maintaining close associations with colleagues with ties to a party. ${ }^{59}$ While candidates for the science panel were not asked to disclose financial assets, they were given a list of defendants in the litigation and informed that any significant current or past relationship, financial or otherwise with any of the defendants, might raise a conflict-ofinterest question.

Some candidates declined almost immediately, indicating either that they did not wish to become involved in this area of litigation or in the legal system in general. One panel member commented that a few candidates saw little prestige in working with the judicial system, and would have preferred that the request come from the National Research Council, an organization highly regarded by scientists. This member stated that if science panels are going to succeed, the scientific community must encourage scientists' participation in the judicial process. Other candidates expressed concern about the amount of time required. Many qualified candidates said they had commitments lasting for years and could not serve on such short notice. Candidates also were concerned about the uncertain nature of the time commitment and required assurance that they would be able to remain productive in their professions. The selection panel told the candidates that the commitment would not extend beyond four to six hours per week for approximately one year, and that Judge Pointer would relieve them of their obligation if unforeseen circumstances so required. ${ }^{60}$

Screening for conflicts of interest was difficult and time-consuming. Many of those contacted, especially toxicologists, had worked in some capacity for one or more of the defendant corporations, either conducting research or serving as a consultant or an expert witness. Such associations often were not mentioned during the telephone conversations. A number of candidates appeared to give full consideration to the issue only when presented with the form requesting written certification of the absence of a conflict. ${ }^{61}$ Identifying candidates who were knowledgeable regarding the scientific specialties, yet openminded regarding the issues in dispute in the litigation, required a number of difficult choices. Many of those most knowledgeable about research on the effects of breast implants were committed to positions disputed in the litigation, so they could not be considered. The selection panel attempted to identify scholars who had knowledge about relevant areas without having participated directly in the research or debate over breast implants. For example, one scientist was familiar with epidemiological studies of breast cancer, but had not re-

59. See id.

60. Almost everyone contacted was curious about the science panel. At the same time, almost all candidates had serious reservations about accepting an appointment. All of those ultimately appointed to the panel declined to serve at least once during the selection process and were persuaded to reconsider.

61. One candidate indicated in the telephone conversation that no conflicts existed, then declined to sign the form after revealing that he had testified on behalf of one of the defendants six months earlier and received payment in the five-figure range. 
viewed the epidemiological literature regarding alleged problems with breast implants.

Another example of the selection panel's concern with the appearance of commitment to a disputed position was its scrutiny of one panel member's participation on a committee of rheumatologists formed to revise the position statement of the American College of Rheumatology ("ACR") on the effects of breast implants. In October 1995, the ACR had issued a statement concluding that "studies provide compelling evidence that silicone implants expose patients to no demonstrable additional risk for connective tissue or rheumatic disease." In April 1996, Dr. Betty Diamond, at the request of the ACR, agreed to serve on a panel to reexamine and possibly update that statement. After reviewing it, the panel recommended adding the following: "and that additional information could be expected with regard to non-traditional diseases." ${ }^{63}$ In the end, the ACR decided not to accept the panel's revision. Because the contents of the statement appeared to take no position on the causation issue with regard to breast implants, the selection panel concluded that her advocacy of a neutral wait-and-see policy for the College was consistent with her role of assessing the evidence impartially.

In general, members of both the selection and expert panel reported that those who accepted the invitation to serve on the science panel were curious about the process and viewed their service as an opportunity to strengthen the presentation of scientific information in a judicial forum. They also placed great weight on the fact that they would be furthering a public interest by serving as court expert. None seemed motivated by traditional professional research interests, because service on the science panel would likely limit the opportunity for traditional scientific achievement during the time of service. Panelists were assured that they could write about their experience upon completion of their service.

Even though the selection panel was permitted to nominate multiple candidates, the panel decided to nominate only one scientist for each position. ${ }^{64}$ In each case, the selection panel unanimously believed that the nominated individual was the best available for the job. Ultimately, the selection panel nominated and the court accepted as the members of the national science panel: Dr. Betty A. Diamond ${ }^{65}$ for immunology, Dr. Barbara S. Hulka ${ }^{66}$ for epidemiology,

62. See Rosenbaum, supra note 38 , at D7.

63. See supra note 37.

64. One expert panel member wished that two people had been appointed from each scientific discipline so that each finding would have been based on the consensus of two experts. Had this proposal been accepted, it would have potentially doubled the cost of the panel.

65. Dr. Diamond is a professor in the Department of Microbiology and Immunology at Albert Einstein College of Medicine in Bronx, New York.

66. Dr. Hulka is the Kenan Professor at the Department of Epidemiology at the School of Public Health at the University of North Carolina, Chapel Hill. 
Dr. Nancy I. Kerkvliet ${ }^{67}$ for toxicology, and Dr. Peter Tugwell ${ }^{68}$ for rheumatology.

\section{INSTRUCTIONS TO THE EXPERT PANEL}

Producing a written report was an important objective of both the Oregon and MDL procedures. In the Oregon litigation, the report was the primary product of the expert panel. In the MDL process, the report served to give focus and structure to the experts' videotaped testimony. The courts' instructions to the expert panel members in both proceedings were intended to define the experts' tasks and to establish a procedure to assist them in carrying out their tasks. Judge Jones designed his instructions to guide the experts in creating a report that would help him decide whether to exclude plaintiffs' scientific evidence at the pretrial stage. ${ }^{69}$ Judge Pointer's instructions were designed to assist the experts in reviewing the scientific literature, producing a written report, and providing testimony for federal and state breast implant trials nationwide. ${ }^{70}$

Several experts in the MDL proceeding, however, thought that their report would be the major product and were surprised to learn that they would have to be deposed, even though the court's Order 31, which preceded their appointment, clearly stated that videotaped depositions would be the ultimate products. All of the experts in both cases noted that many of their concerns should be expected when "naïve" scientists or physicians, without previous experience as experts, participate in a judicial process with which they are not familiar.

In this section, we describe the scope of the instructions in these two cases, consider similarities and differences between them, and highlight issues and concerns raised. The instructions differed in several ways, including timing, the definition of the experts' duties, and the extent to which the initial instructions were supplemented. As both the Oregon and MDL processes unfolded, clarification or elaboration of several instructions or questions became necessary. During interviews, participants in both processes emphasized the need for clearer instructions and more guidance from the court.

67. Dr. Kerkvliet is a professor and extension toxicology specialist in the Department of Agricultural Chemistry at Oregon State University in Corvallis, Oregon.

68. Dr. Tugwell is a professor and the chairman of the Department of Medicine at the University of Ottawa in Ottawa.

69. See Hall v. Baxter Healthcare Corp., 947 F. Supp. 1387, 1393 (D. Or. 1996).

70. See Order No. 31, Appointment of Rule 706 Expert Witnesses, In re Silicone Gel Breast Implants Prods. Liab. Litig. (MDL 926) (No. CV92-P-10000-S) (visited Jan. 29, 2001) $<$ http://earth.fjc.gov/ BREIMLIT/ORDERS/order31.rtf>; Order No. 31E, Directions to National Science Panel under FRE 706, Silicone Gel Breast Implants (MDL 926), 793 F. Supp. 1098 (J.P.M.L. 1992) (No. CV92-P-10000-S) (visited Jan. 29, 2001) <http:// earth.fjc.gov/BREIMLIT/ORDERS/order 31e.rtf $>$. 


\section{A. Hall v. Baxter Healthcare Corp.}

Judge Jones instructed the technical advisors to assist him in determining whether the parties' expert testimony rested on reliable scientific methodology. At a pretrial hearing, Judge Jones, the special master, and three of the technical advisors asked the parties' expert witnesses questions about the basis of their testimony. ${ }^{71}$ Following this hearing, Judge Jones asked each counsel to propose questions for the technical advisors. ${ }^{72}$ After reviewing the submissions, Judge Jones drafted the following five questions:

1) Is the expert's opinion supported by scientific reasoning and methodology that is generally accepted in the expert's particular scientific community or otherwise qualified?

2) Is the expert's opinion based upon scientifically reliable data?

3) If epidemiological studies have not been done or are inconclusive, what other data, such as animal studies, biophysical data, clinical experience in the field, medical records, differential diagnosis, preliminary studies, general scientific knowledge, and medical literature can justify, to a reasonable medical probability, a conclusion concerning the cause of the syndrome or disease at issue?

4) Do the methodology and data support the expert's conclusions?

5) Do the scientific data relied upon by the expert apply to the syndrome or disease at issue in these cases? For instance, are epidemiological studies directed at other typical or classical diseases relevant to an atypical disease? ${ }^{73}$

The questions were intended to guide the advisors as they considered issues of relevancy, fit, and validity of plaintiffs' experts' evidence. ${ }^{74}$

Dr. Jones indicated that he and the advisors would have welcomed more definitive instructions from the court earlier in the process, especially due to their unfamiliarity with judicial procedures. ${ }^{75}$ One advisor said, "The most difficult part was knowing the assignment." Another called for "better instructions as to our specific duties." A third observed that "the lack of guidance regarding the task created confusion," and the fourth found that "changing expectations regarding what was expected of us complicated our assignment." Dr. Jones acknowledged, however, that providing such instruction was made more difficult because of the evolving nature of the process.

The fourth question- "Does the methodology and data support the expert's conclusion?"- generated considerable commentary from the advisors and the parties' counsel. This instruction incorporates the Supreme Court's direction in Daubert v. Merrill Dow Pharmaceuticals, Inc., that in assessing whether the basis for expert testimony is scientifically valid, the court must focus "solely on

71. See Hall, 947 F. Supp. at 1393.

72. See id.

73. $I d$.

74. In addition to the judge's five questions, the court included all but one of counsels' proposed twenty or so questions and instructed the advisors to respond to any that they thought would help the court in its gatekeeping role.

75. See supra note 37 regarding information from confidential author interviews. 
principles and methodology, not on the conclusions that they generate." "76 From a scientist's perspective, however, there is no clear delineation between methodology and conclusion; the methods frame the conclusion, which then leads to alternative methods for the next study. The attorneys created further confusion by attempting to clarify the distinction between methodology and conclusion. One attorney, for example, urged the advisors "to consider only the methodology, not the conclusions," but went on to discuss the conclusions.

Judge Jones agreed that the methodology/conclusion distinction under Daubert presented a difficult issue. Anticipating the Supreme Court's resolution of this issue, he indicated in his opinion that

[t]here appears to be no clear demarcation between scientific methodology and the conclusions it generates. Daubert I acknowledged this much, recognizing that science is a process, not "an encyclopedic body of knowledge." This court need not and should not ignore any step in the process, but must ensure that in each step, from initial premise to ultimate conclusion, the expert faithfully followed valid scientific methodology. In other words, this court need not accept, as scientifically reliable, any conclusion that good science does not permit to be drawn from the underlying data but, which, instead constitutes "unsupported speculation."

Dr. Jones commented that distinguishing between methodology and conclusion is difficult when the findings involve a chain of reasoning that is tied to research methods. He argued that scientists should be permitted to comment on the validity of inferences and conclusions, because a valid method may be applied inappropriately.

Judge Jones asked Dr. Richard Jones to continue to serve as special master after the appointment of the expert panel. On occasion, Dr. Jones served as an intermediary, fielding questions from the panel members and bringing those questions to Judge Jones or the parties. This approach reduced instances of ex parte communication with Judge Jones ${ }^{78}$ and allowed for instruction of the ex-

76. 509 U.S. 579,595 (1993).

77. Hall, 947 F. Supp. at 1401 (citation omitted) (quoting Daubert, 509 U.S. at 590). Following Hall, the Supreme Court addressed this issue:

But conclusions and methodology are not entirely distinct from one another. Trained experts commonly extrapolate from existing data. But nothing in either Daubert or the Federal Rules of Evidence requires a district court to admit opinion evidence which is connected to existing data only by the ipse dixit of the expert. A court may conclude that there is simply too great an analytical gap between the data and the opinion proffered.

Joiner v. General Electric Co., 522 U.S. 136, 146 (1997).

78. In general, case law and canons of judicial ethics discourage any type of ex parte communication regarding substantive matters between the judge and court-appointed experts acting as witnesses during the course of litigation. See CECIL \& WILlgIng, supra note 31, at 39-43. When the expert serves as a technical advisor, and therefore as a consultant to a judge, ex parte communication with the judge sometimes occurs. But even here, appellate courts have cautioned that judges should follow certain procedural safeguards. See Reilly v. United States, 863 F.2d 149, 158-60 (1st Cir. 1988) (holding that the ground rules governing communication with a technical advisor included advising parties if the expert ranged into an area not discussed in the briefs; and recommending the inclusion of a comprehensive job description on the record and the submission of an affidavit of the expert's compliance with the ground rules at the end of the appointment). 
perts in their tasks while permitting Judge Jones to maintain sufficient distance from the work of the panel..$^{79}$

\section{B. In re Silicone Gel Breast Implant Products Liability Litigation}

After issuing the written instructions, ${ }^{80}$ Judge Pointer held a two-day orientation conference, which included an overview of the events leading to the experts' appointment and a description of their roles and responsibilities. ${ }^{81}$ Stressing that the experts were not being asked to perform independent research or to examine patients, Judge Pointer called upon them to look at the various scientific studies and reports and to make professional judgments as to whether they could ascertain a reliable scientific basis within their disciplines for drawing certain conclusions, such as whether implants cause or exacerbate specified conditions. ${ }^{82}$

In his written instructions Judge Pointer asked the court-appointed experts to respond to the following questions:

(a)Issues. To what extent, if any, and with what limitations and caveats do existing studies, research, and reported observations provide a reliable and reasonable scientific basis for one to conclude that silicone-gel breast implants cause or exacerbate any of the conditions described in (b) below? If, in the process of making these findings, you believe that there are related or subordinate issues that should be separately addressed, please do so.

(b) Scope. You are asked at this time to consider the relationship, if any, between implants and the following:

i) "classic" connective tissue diseases, such as systemic lupus erythematosus, Sjögren's syndrome, etc.

ii) "atypical" presentations of connective tissue diseases or symptoms

79. We are aware of no instances of direct communication between Judge Jones and the expert panelists regarding substantive matters. In one instance, however, an expert sought clarification of a statement regarding precision of a certain measurement that had been relied upon at the preliminary hearing. When Judge Jones declined to reopen the record to clarify this issue, the expert on his own initiative contacted the manufacturer of the laboratory instrument to determine if it was capable of making the disputed measurement. This approach amounted to an indirect form of ex parte communication with the decisionmaker.

80. Federal Rule of Evidence 706(a) requires written instructions or a conference with the court's experts.

81. Transcript of National Science Panel Hearing, Oct. 24, 1996, In re Silicone Gel Breast Implants Prods. Liab. Litig. (MDL 926), 793 F. Supp. 1098 (J.P.M.L. 1992) (No. CV92-P-10000-S) [hereinafter Transcript].

82. Id. at 13-14. The parties were allowed to participate in drafting the instructions. Before the orientation conference, Judge Pointer discussed the experts' duties with parties' counsel, and the attorneys reviewed and commented on the court's proposed instructions. Judge Pointer included many of the parties' suggestions, but limited the number of systemic injury symptoms for the experts to consider to approximately twenty-five. Listed in the appendix of the court's order were various diseases, symptoms, conditions, and complaints sometimes asserted as possibly associated with siliconegel implants. The experts were encouraged to comment on the scientific basis, if any, for this claimed linkage. They were not asked to consider purely local complications, such as breast disfigurement, tenderness, or capsular contracture. See Order No. 31E, Directions to National Science Panel under FRE 706, Silicone Gel Breast Implants (No. CV92-P-10000-S) (visited Jan. 29, 2001) $<$ http://earth.fjc.gov/BREIMLIT/ ORDERS/order31e.rtf>. 
iii) immune system dysfunctions

- .

(c) Contrary Opinions. To what extent, if any, should any of your opinions referenced in (a) above be considered as subject to sufficient genuine dispute as would permit other persons, generally qualified in your field of expertise, to express opinions that, though contrary to yours, would likely be viewed by others in the field as representing legitimate and responsible disagreement within your profession? ? $^{83}$

During the conference, the experts were given an opportunity to review and comment on the court's proposed instructions. They were asked to point out any issues that were not clear and indicate whether they felt comfortable performing the tasks outlined in the instructions. The experts expressed no reservations regarding the instructions at that time.

Judge Pointer also instructed panel members orally on the procedures to be followed regarding consultation among themselves, consultation with authors of studies, obtaining special assistance or advice from other experts, preparation of reports, and procedures for presenting deposition testimony. ${ }^{84}$ As reported below, some of these oral instructions were unclear to the experts and counsel.

Throughout the process, issues arose about proper communication between the judge and panel, and among panel and non-panel members. In an early order, litigants and implant recipients, their counsel, and their potential lay or expert witnesses were enjoined from directly communicating with any of the members of the panel regarding issues in breast-implant litigation. ${ }^{85}$

Judge Pointer initially anticipated appointing a fifth panel member to serve as an administrator and coordinator of the panel activities. He also anticipated communicating directly with the panel members, but defense counsel objected to direct communications, fearing that such communication would compromise the work of the panel. ${ }^{86}$ Also, it soon became clear that the experts' lack of familiarity with the legal process, and the deposition process in particular, made it necessary to appoint counsel to represent their interests in those proceedings. Consequently, in January 1997, Judge Pointer appointed John M. Kobayashi to act as "special, independent, and private counsel to the members of the $\mathrm{Na}$ tional Science Panel." ${ }^{97}$ Mr. Kobayashi was authorized to contact parties, their counsel, and the court, singly or in combination, "mindful, however, of the obli-

83. Order No. 31E, Directions to National Science Panel under FRE 706, Silicone Gel Breast Implants (No. CV92-P-10000-S) (visited Jan. 29, 2001) <http://earth.fjc.gov/BREIMLIT/ORDERS/order31e.rtf $>$.

84. See Transcript, supra note 81.

85. See Order No. 31D, Appointing Additional Member of National Science Panel and Precluding Ex Parte Communications with Panel Members, Silicone Gel Breast Implants (No. CV92-P-10000-S) (visited on Jan. 29, 2001) < http://earth.fjc.gov/ BREIMLIT/ORDERS/order31d.rtf >.

86. See, e.g., Edgar v. K.L., 93 F.3d 256, 256 (7th Cir. 1996) (addressing judge's action in meeting ex parte with panel of experts appointed by judge; action was grounds for disqualification of judge).

87. Order No. 31F, Appointment of Special Counsel to National Science Panel, Silicone Gel Breast Implants (No. CV92-P-10000-S) (visited Jan. 29, 2001) <http://earth.fjc.gov/BREIMLIT/ORDERS /order31f.rtf $>$. 
gation not to engage in communications that might be viewed as inappropriate ex parte communications involving substantive matters." $"{ }^{88}$

Judge Pointer ordered that all communication between panel members and special counsel would be subject to the attorney-client privilege. ${ }^{89}$ Mr. Kobayashi also delivered communications to the expert panel members from Judge Pointer, including those regarding administrative matters such as billing, payment, and scheduling hearings. In a few instances, Judge Pointer and the experts spoke directly when communication between the experts and special counsel appeared to break down. Several of the experts had difficulty contacting Mr. Kobayashi, so they called Judge Pointer's chambers directly with their questions and requests. Occasionally, when discussing administrative matters with a member of Judge Pointer's staff, an expert would raise a substantive question. Judge Pointer reported these contacts and the substance of his response to the parties. Attorneys for the defendants, who initially objected to a proposal permitting ex parte communications between Judge Pointer and the expert panel members, reported that this process worked well. Attorneys for the plaintiffs had not objected to the initial proposal, and expressed no concerns about this ex parte communication between Judge Pointer and the experts.

There was one known instance of direct contact between a panel member and a party, in which the panel member appeared on a symposium panel unrelated to breast implants that was organized and sponsored by one of the defendants. This interaction became the topic of an extended hearing, discussed in Part V.

Participants provided a range of comments regarding the court's oral and written instructions. Generally, the panel expressed confusion about how to conduct their work, frustration about restrictions on their day-to-day activities, and concern about the confidentiality of their notes and conversations. One expert commented that the oral instructions seemed fine initially, but the panel later realized that all instructions should have been written and affirmed by all involved. Some panelists had difficulties even with the court's written instructions. According to one panel member,

they were precise from a legal standpoint, but the panel had to work hard to figure out what the questions really were. Only then could [the panel] decide who would cover what area. There were a lot of options for organizing the work, and the way we did it is only one of many possibilities. What we ended up with, though, was appropriate and it was appropriate for the court to leave it to us to figure out how to organize our work.

Another panel member commented that they were told to be careful about drafts, but she was not aware that this would extend to scribbling notes on articles. At the outset, Judge Pointer had advised the panel members to revise their computer-based drafts, as he does, without saving the old ones. Judge

88. Id.

89. See id. 
Pointer, however, said that he could not advise them whether earlier drafts would or would not have to be produced.

The experts agreed that the initial screening for conflicts of interest was done in good faith but did not anticipate issues that arose later. One expert commented that the court should have had written instructions on conflicts of interest. Having such a section would have minimized a lot of the confusion surrounding appropriate communications with parties and nonparties. Several experts noted that, as time passed, the definition of what seemed to be a conflict changed. Judge Pointer agreed, noting that more time should have been spent preparing special instructions on conflicts and periodically reemphasizing these issues. At the same time, he feared that a more detailed instruction regarding conflicts could overstate the problem of communication with representatives of the parties and might have discouraged the selected experts from serving. In fact, had such a provision been in place, at least one expert would not have served on the panel.

The attorneys on both sides also had concerns about the instructions. One plaintiffs' attorney thought that Judge Pointer's oral instruction implied that the experts were entitled to keep their opinions, correspondence, and other communications secret. This attorney thought that the experts should have had no more protection than any other party's expert. In the attorney's opinion, it was inappropriate for the court to allow the experts to work together as a group and keep their deliberations secret. Another plaintiffs' attorney thought the instructions were clear except for the standard of proof question. The attorney was concerned that Judge Pointer instructed the panel members to apply the standard of proof used in their respective fields. As a result, panel members used the scientific standard, which requires greater certainty than the legal standard of a preponderance of the evidence. This attorney believed the scientific standard was the wrong standard to use.

On the other side, several defendants' attorneys thought the first question concerning causation issues was fine but that the second question regarding acceptable minority views was not sufficiently clear. These attorneys thought the court was asking the panel to criticize other scientists and their methods, an uncommon practice among scientists.

\section{V}

\section{COLLECTING SCIENTIFIC INFORMATION AND PRODUCING THE REPORTS}

In this section, we discuss the information on which the report was based, the form of the report, the experts' division of labor, the need for assistance and expertise, administrative matters relating to the production of the report, and the attorneys' perceptions of the attorneys about the usefulness of the report.

\section{A. Hall v. Baxter Healthcare Corp.}

In the Oregon litigation, the advisors received scientific information in three ways. First, Judge Jones structured a four-day pretrial hearing on the admissi- 
bility of expert evidence, with one day devoted to each of the four subject matter areas. ${ }^{90}$ During the hearing, the experts and the special master listened as the parties' experts presented their views in narrative form. Opposing counsel then cross-examined the experts, but without evidentiary objections. Judge Jones limited opposing counsel's questions to those addressing science issues, ruling out questions regarding bias and funding of the research. Judge Jones and the technical advisors also asked questions of the parties' experts about the basis of their testimony.

Second, following the hearing, the parties provided the panel of advisors with numerous boxes of articles and other written materials. The technical advisors were initially overwhelmed by the amount of material to be reviewed in a brief period of time. According to one advisor, the material submitted by the parties should have been better organized. ${ }^{91}$ The advisors did not feel they received the guidance needed to undertake their review.

Third, Judge Jones ordered the parties to prepare videotaped summations for the technical advisors, allowing each side thirty minutes per discipline and allowing plaintiffs forty minutes for rebuttal. ${ }^{92}$

To assist the technical advisors and minimize ex parte communication, Judge Jones asked Dr. Jones to continue to serve as special master following appointment of the expert panel. Dr. Jones assisted the technical advisors by (1) offering guidance regarding their tasks, which involved interpreting the court's instructions in some instances; (2) contacting Judge Jones with questions about communications with other scientists; and (3) reviewing drafts of reports to ensure they were responsive to the court's questions and understandable to a non-scientist. ${ }^{93}$ Judge Jones' questions provided some structure for developing the report, but since he required that the advisors prepare separate reports and not exchange reports prior to submission to the court, the advisors only needed to communicate to decide how to divide specific topics among the panel members. Two experts with overlapping areas of expertise discussed how they should divide certain issues involving both immunology and rheumatology but ultimately worked independently. The advisors found the lack of specific guidance regarding the relationship between methodology and conclusions and the treatment of minority viewpoints especially problematic. In the end, the advisors' separate reports included inconsistent views.

90. See Hall v. Baxter Healthcare Corp., 947 F. Supp. 1387, 1393 (D. Or. 1996).

91. See supra note 37.

92. See Hall, 947 F. Supp. at 1393.

93. As a result of Dr. McClard's late appointment, he had only a few weeks to prepare his report. Understandably, he had a great number of questions about the evidentiary hearing and report preparation. Consequently, Dr. Jones worked more closely with Dr. McClard than with the other technical advisors. He answered Dr. McClard's general questions, such as how to locate items in the court record. Dr. Jones offered no opinion or judgment regarding the merits of the issues in dispute, but he did help focus Dr. McClard's inquiry on the relevant issues. Further, Dr. Jones also reviewed a draft of Dr. McClard's opinion and suggested minor revisions to several phrases that he thought might be misunderstood. 


\section{B. In re Silicone Gel Breast Implant Products Liability Litigation}

In the MDL proceedings, the experts also received information in three ways. First, Judge Pointer arranged a three-day conference at which the party experts presented their views and engaged in informal discussions with the panel members. ${ }^{94}$ Subsequently, the panel members, with the assistance of special counsel, convened a conference of scientists in Washington, D.C., which Judge Pointer attended. Second, the experts reviewed articles and other written materials transmitted through the special counsel's office. In all, the parties submitted over thirty-five linear feet of written material, the bulk of which was presented to the experts. ${ }^{95}$ At Judge Pointer's urging, the parties formulated priority lists of forty articles per expert for each side and a "top 100" listing overall. Third, each of the experts conducted his or her own searches. Such searches rarely turned up information that the parties did not provide as part of their submissions. At the trial deposition stage, the parties listed hundreds of additional articles as possible bases for cross-examination. Nevertheless, this independent search assured panel members that their opinions were based on a thorough review of the literature.

1. Individual Versus Joint Reports. In his initial instructions to the selection panel, Judge Pointer recommended that each expert prepare an individual report, drawing on other panelists' expertise, as soon as all or a discrete portion of the assignment had been contemplated and an initial finding could be made. ${ }^{96}$ This instruction was intended to create an identifiable body of work linked to each panel member to frame his or her direct testimony and focus any crossexamination. As the work evolved, the panelists combined their individual efforts into a single report after they agreed that there was no reasonable and reliable scientific basis to conclude that silicone gel breast implants cause or exacerbate the specified diseases. Thus, there was little or no reason for separate reports. To address the need for individual accountability, each panelist wrote a separate chapter. All four panelists then signed the final report and linked their findings by an executive summary that included an introductory section explaining the common background for the report. The executive summary concluded with a joint statement responding to Judge Pointer's question about opinions contrary to those of the panel members. ${ }^{97}$

There was considerable overlap in the qualifications and disciplines of the panel members. Although Dr. Diamond was appointed as an immunologist and

94. See Transcript of Rule 706 Panel Hearing Before the Honorable Sam C. Pointer, Jr. (July 2224,1997 ) (on file with authors).

95. The panel expressed concern about the volume of material it received and the length of time it took to review the documents. Initially, the panel was given eleven large boxes containing thousands of documents.

96. See Order No. 31, Appointment of Rule 706 Expert Witnesses, In re Silicone Gel Breast Implants Prods. Liab. Litig. (MDL 926), 793 F. Supp. 1098 (J.P.M.L. 1992) (No. CV92-P-10000-S) (visited Jan. 29, 2001) <http://earth.fjc.gov/BREIMLIT/ORDERS/order31.rtf>.

97. See National Science Panel, supra note 15, at 8. 
Dr. Kerkvliet as a toxicologist, both dealt with immune system responses to foreign substances. They divided the labor so that Dr. Diamond considered research on human immunology and Dr. Kerkvliet examined animal studies. Also, Dr. Hulka was appointed as an epidemiologist and Dr. Tugwell as a rheumatologist. To address rheumatological issues, however, Dr. Tugwell relied primarily on epidemiological methods. Each of their separate chapters reflected similar methods and analyses. ${ }^{98}$

2. Communications Among Panel Members and with Colleagues. Judge Pointer indicated that the panel members were free to communicate with each other as needed. ${ }^{99}$ Mr. Kobayashi, special counsel, was concerned that the subject of such communication could become a topic for discovery. He attempted to bring these communications into the protection of attorney-client privilege by setting up a special telephone line and urging the panel members to communicate with each other only when an attorney from his office was on the line. The experts found this restriction both awkward and inconvenient and soon began to engage in direct telephone and e-mail communications. The experts needed this communication to coordinate their work on a single comprehensive report.

Another point of tension between Mr. Kobayashi and the panel members involved the experts communicating with colleagues not serving on the panel as they reviewed the literature and prepared their report. Because the panel members had not conducted research on the effects of silicone gel breast implants, they wished to consult with others who were experienced in this area. At the first meeting in Birmingham, one panel member asked Judge Pointer about consulting with colleagues not involved in the litigation and was told that such consultations were permissible if the researchers recorded the inquiries in a log. ${ }^{100}$ If the panel member wished to ask questions of an author of one of the papers being reviewed for the litigation, the inquiry could involve questions to clarify an understanding of data in a research study, but not an interpretation of the data. Making this distinction, however, proved difficult. ${ }^{101}$

The experts in Judge Pointer's litigation found that these constraints discouraged occasional consultation with colleagues. ${ }^{102}$ The panel member who went through the preclearance process to contact two persons in her academic department was later surprised to learn that their identities were reported to the parties' attorneys. After that, she was reluctant to approach colleagues for fear of involving them in the litigation. Other panel members did not contact colleagues, either because they were concerned or confused about the condi-

98. See id. at 2.

99. See Transcript of National Science Panel Hearing Held Before the Honorable Sam C. Pointer, Jr., at 27 (Oct. 24, 1996) (on file with authors) [hereinafter Science Panel Hearing].

100. See id. at 55-56.

101. See supra note 37.

102. The need for such consultations was mitigated by the Washington, D.C. hearing. See Science Panel Hearing, supra note 99. 
tions governing such contacts, or because they wanted to develop their independent judgment of the issues. One panel member suggested clearer rules and a document they could send to colleagues that would set forth the extent of their involvement and the consequences of responding to an inquiry by a panel member.

3. The Expert Panel's Report. In November 1998, the panel members produced a report consisting of four chapters, each written by one panel member, linked by a common introduction, conclusion, and executive summary. ${ }^{103}$ There was a general consensus among the panel members with respect to causation issues and the possible effects of exposure to silicone gel. ${ }^{104}$ Specifically, the toxicologist concluded that "[t]he preponderance of data from [animal] studies indicate [sic] that silicone implants do not alter incidence or severity of autoimmune disease." 105 Also, "[c]onsidering the broad range of testing systems that have been used in the study of silicone effects, the toxicologic and immunologic responses are few in number and questionable in significance." ${ }^{106}$ The immunologist found that many of the studies available for analysis were methodologically inadequate, with ill-defined or inappropriate comparison subjects or unorthodox data analyses. ${ }^{107}$ Because of these limitations, among others, she concluded from existing studies that women with silicone breast implants do not display a silicone-induced systemic abnormality in the types or functions of cells of the immune system. ${ }^{108}$ The epidemiologist found "no association . . . between breast implants and any of the individual connective tissue diseases, all definite connective diseases combined, or the other autoimmune/rheumatic conditions." ${ }^{109}$ Finally, the rheumatologist found problems with many of the studies.

$[\mathrm{T}]$ he same complaint appeared in more than one disease category; self-report was not verified; timing of the complaint in relation to the implant was not known; indication for the implant was ignored; and in individual studies, the number of affected women was small. Furthermore, many of the rheumatologic complaints reported are common in the general population and . . . in physicians' offices. No distinctive features relating to silicone breast implants could be identified.

4. Attorneys' Views of the Usefulness of the Report. Attorneys' views about the usefulness of the report were directly related to the extent to which the report supported their claims. In general, for the reasons discussed below, attorneys for defendants found the report and the videotaped testimony extremely useful, and expected to use them in any trials about systemic issues

103. See National Science Panel, supra note 15.

104. See id. at 4-8.

105. Id at 4.

106. $I d$. at 5 .

107. See id. at 5-6.

108. See id. at 6 .

109. Id. at 6 .

110. Id. at 7 . 
and in any Daubert hearings that might precede these trials. ${ }^{111}$ On the other hand, as discussed below, attorneys for plaintiffs think the report and testimony are worth very little and expect to challenge their use at every juncture. ${ }^{12}$ Attorneys on both sides have doubts about the life expectancy of the report and testimony. ${ }^{113}$

All defendants' attorneys, and even one plaintiffs' attorney, found that the report matched the issues in the litigation well, but other plaintiffs' attorneys identified a number of gaps in the report. For example, one argued that the experts ignored significant studies. ${ }^{114}$ Others believed the absence of views from a pathologist or a polymer chemist to be fatal. Still another attorney focused on the absence of clinical findings, arguing that the report, by its terms, addressed the general causation issues only in terms of existing scientific research, and could not be used to exclude clinical evidence that illnesses arose following the implants and were cured when the implants were removed. All agree that, except in extraordinary circumstances, the report itself will not be independently admissible as evidence. A plaintiffs' attorney would argue that the report "is not the type of information that an expert would ordinarily rely on." Furthermore, "an expert relying on the report would have to answer some very difficult questions." Another attorney noted that the utility of the report and videotaped testimony is limited, because they relate entirely to evidence of systemic injuries and do not consider local injuries. Plaintiffs plan to emphasize local injuries, which they believe are present in many, if not all, of the remaining cases.

VI

\section{DISCOVERY AND DEPOSITIONS OF THE EXPERTS}

Candidates for appointment as experts often express concern about the extent to which their opinions will be subject to deposition and cross-examination. Scientists view a proper inquiry as limited to the opinions and information expressed in the research report, especially where the experts are court-appointed and are unlikely to have been influenced by contact with the parties. ${ }^{115}$ Any inquiry into factors not directly related to the report, such as the personal motivations of the researcher or opinions on matters outside the report, is regarded as

111. In addition, some defendants' attorneys thought the report would dissuade plaintiffs' experts from testifying because it stripped away any professional basis for their previous testimony.

112. Some plaintiffs' attorneys, for example, thought that the report did not adequately deal with reliable findings of clinicians, pathologists, chemists, and other professionals not represented on the panel.

113. Attorneys were aware that a then-pending National Institutes of Health study might alter the basis for the national panel's conclusion. See Louise A. Brinton et al., Breast Cancer Following Augmentation Mammoplasty, 11 CANCER CAUSES \& CONTROL 819 (2000).

114. See supra note 37.

115. See Order No. 31L, Denying Plaintiffs' "Motion for Relief from Prejudicial Bias," Apr. 25, 1999, at 14, In re Silicone Gel Breast Implants Prods. Liab. Litig. (MDL 926), 793 F. Supp. 1098 (J.P.M.L. 1992) (No. CV92-P-10000-S) (visited Jan. 29, 2001) <http://earth.fjc.gov/BREIMLIT/ ORDERS/order311.rtf>. 
an unnecessary attack on the integrity of the individual. ${ }^{116}$ In both of these cases, the court fashioned a compromise procedure that permitted the attorneys to inquire into the bases of the expert panel members' opinions while constraining the inquiry relative to its traditional scope.

\section{A. Hall v. Baxter Healthcare Corp.}

Judge Jones did not contemplate depositions of the experts, because they were to serve as technical advisors, not witnesses. Judge Jones appointed the experts pursuant to a court's inherent authority to seek technical advice and assistance and, thus, concluded that the requirements of Rule 706 relating to depositions, testimony, and cross-examination did not apply. ${ }^{117}$

Three days after the technical advisors submitted their reports, the court conducted a hearing at which parties' counsel questioned the advisors. ${ }^{118}$ Judge Jones clarified that this hearing was not a deposition, but rather a chance for the attorneys to ask questions about the bases of the advisors' reports. Almost all of the plaintiffs' attorneys, and a number of defense attorneys, thought that this hearing did not provide an adequate opportunity to question the advisors about their findings and conclusions. Similarly, one technical advisor believed the hearing was not a true "cross-examination" 119 and thought that he and the other advisors should have been deposed. Upon reflection, Judge Jones thought that having advisors provide testimony in open court may have created some confusion regarding their role, because advisors who serve as court consultants are not generally deposed; but he was still satisfied with the workings of the process.

\section{B. In re Silicone Gel Breast Implant Products Liability Litigation}

Judge Pointer sought to create an informal atmosphere that would be comfortable for the experts, while giving the parties the opportunity to discover information relevant to the videotaped trial depositions that were to follow a couple of months later. ${ }^{120}$

1. Discovery Deposition Format. Judge Pointer established the ground rules for and presided at discovery depositions conducted in a law firm's conference room. These depositions were transcribed by a court reporter, but were not videotaped. Each side was allowed a maximum of three hours to examine each witness. Only one attorney from each side was permitted to question a given panel member. Panelists were allowed to be present while the

116. See id.

117. See Hall v. Baxter Healthcare Corp., 947 F. Supp. 1387, 1392 n.8 (D. Or. 1996).

118. See id. at 1394.

119. See supra note 37.

120. As the MDL judge presiding over a national docket of cases, Judge Pointer had to be concerned that a ruling or other limitation on cross-examination could render the deposition testimony inadmissible at trial. Multiple standards might apply in various trial courts in which the testimony might be used. 
others testified. Before the depositions, counsel were ordered to submit general wording of all questions to be asked each witness, and copies of these questions were provided to the witnesses. ${ }^{121}$ If a question referred to an article not cited in the report, a copy of that article was to be attached to the request. In all, counsel asked the experts hundreds of questions, ranging from detailed questions about particular studies to general questions about the panelist's background. ${ }^{122}$ Questions typically were related to the process of conducting the research and to the substance of the science issues. ${ }^{123}$ Plaintiffs' questions were generally more in the style of a cross-examination and defendants' questions generally were more expository. ${ }^{124}$

The deposition process could be described as one of flexible informality. Some questions, especially those dealing with the process of preparing the report, were posed to more than one panelist in an informal "joint deposition" format. If a panel member did not know the answer to a question, he or she could refer it to another panel member. ${ }^{125}$

a. Plaintiffs' requests for documents. In December 1998, plaintiffs' attorneys requested, among other items, copies of the experts' notes and any other evidence of communications among panel members concerning preparation of the report-including communications with counsel-as well as drafts of the report or any outlines. ${ }^{126}$ Defendants and special counsel objected. After the parties were unable to resolve the issues in dispute, Judge Pointer directed the parties to brief two issues: "(1) whether communications among panelists may be discovered; and (2) whether the parties are entitled to discovery of the panelists' drafts and working notes." ${ }^{127}$

121. See Order No. 31I, Protocol for Discovery Depositions, Dec. 21, 1998, In re Silicone Gel Breast Implants Prods. Liab. Litig. (MDL 926), 793 F. Supp. 1098 (J.P.M.L. 1992) (No. CV92-P-10000-S) (visited Jan. 29, 2001) <http://earth.fjc.gov/BREIMLIT/ORDERS/order31i.rtf>.

122. See Handouts, Predeposition Conference with Judge Sam C. Pointer, Feb. 3, 1999, Silicone Gel Breast Implants (No. CV92-P-10000-S) (on file with authors).

123. See id.

124. Some examples of plaintiffs' attorneys questions give a flavor of the confrontational questions the panelist faced. Plaintiffs' background questions included: "Are you an expert in the following areas: toxicology, pathology, polymer chemistry, neurology, or epidemiology?" and "Have you conducted any original research on silicone or breast implants?" See id. Plaintiffs' process questions included: "In preparing for your testimony today, please tell us what you reviewed, who you met with, what was said, who else was present, and what else, if anything, did you do?" and "Did the panel adopt any procedures for reviewing the materials and preparing the report?" Plaintiffs' questions addressing the science issues included: "Do you find granuloma in healthy individuals or is that an indication of a disease process?" and "What criteria did you use to determine if the elevation of risk in the studies referenced on Page IV-7 are substantial or consistent and what epidemiological literature do you rely on for your criteria?" The nature of these questions can be explained by the comment of one plaintiffs' attorney, who indicated that the PSC attorneys were representing plaintiffs' attorneys across the country and accordingly felt pressure to be especially thorough.

125. Sometimes special counsel would whisper to the expert after a question was asked, but no one objected.

126. See Plaintiffs' Memorandum on Discoverability at 3, Silicone Gel Breast Implants (No. CV92-P10000-S).

127. Id. at 1 . 
Plaintiffs argued that their right to obtain notes, drafts, and other materials was a central part of their right under Rule 706 to cross-examine a courtappointed expert and that the materials sought were clearly within the scope of discovery as set out in Federal Rule of Civil Procedure 26. ${ }^{128}$ Defendants claimed that the request included material that was privileged because it was used in the decisionmaking process, analogizing to cases involving arbitrators, hearing examiners, and other decisionmakers. ${ }^{129}$ In reply, plaintiffs argued that the panelists were witnesses, not adjudicators. ${ }^{130}$

Judge Pointer did not issue a ruling on the general request for documents. Rather, he ruled on requests for specifically identified documents. ${ }^{131}$ On several occasions, he examined an item in camera before ruling on its discoverability. ${ }^{132}$ Judge Pointer first ruled that the "Summary of Review of Articles," which two colleagues had prepared at one expert's request, was discoverable. ${ }^{133}$ In that ruling, he decided that the work of the panelists generally is a proper subject of inquiry and production. He rejected the general "decisionmaking privilege" claim. ${ }^{134}$ To reassure the experts, he commented that examining notes or preliminary reports need not be a source of embarrassment and suggested to the attorneys that examining the details of such drafts may be a waste of time. ${ }^{135}$

b. Examination on contacts with party representatives. Plaintiffs' and defendants' attorneys questioned the experts regarding their contacts with colleagues who served as party consultants. On several occasions, the experts had professional contacts with the party experts, but these contacts were not related to silicone gel breast implants. For example, one expert co-authored an article with an expert witness for a defendant, and another expert participated in a symposium with a party expert. ${ }^{136}$ The experts also took precautions to keep the contacts professional. One expert knew that faculty colleagues had consulting relationships with defendants, and avoided talking with these colleagues about silicone gel breast implants. ${ }^{137}$

128. See id. at 5-13.

129. See generally Transcript of Rule 706 Panel Hearing Before the Honorable Sam C. Pointer, Jr. at 15-16 (Feb. 4, 1999) (on file with authors) (ruling rejecting defendants' claim of privilege).

130. Special counsel participated in a conference call with Judge Pointer and the defendants' attorneys considering the plaintiffs' request but did not file a brief or other written argument relating to the request. In response to the request, special counsel produced documents from two of the experts, including a record of all telephone calls from one expert's office during a two-year period, not limited to calls in which breast implants were discussed. Both experts turned over notes and critiques, and one provided a copy of her original working outline. See id. at 6.

131. See id. at 8,15 .

132. See id. at 245-47.

133. See id. at 15-16.

134. Id.

135. See id. at 16.

136. See id. at $51-53,154$.

137. See id. at $83,152-53$. 
The experts were not always able to take these precautions, however. One expert had problematic contact with a paid consultant for a defendant. ${ }^{138}$ Their conversation dealt with the consultant's opinions on various studies that were central to the issues under review, the consultant's opinion on the validity of legal claims, and the consultant's recommendation of a book seen as favoring defendants' viewpoints. ${ }^{139}$ Because the expert was not aware of the consulting relationship, she thought the consultant's interest was purely scientific and put the consultant's name on the panel for the Washington, D.C. meeting. ${ }^{140}$

c. Attorneys' reactions. With few exceptions, both plaintiffs' and defendants' attorneys thought the process for discovery depositions was fair. Neither side felt that they got all of the procedural benefits they sought, but on balance both found that the process met their clients' needs and interests.

Not surprisingly, defendants liked having the questions submitted in advance, while plaintiffs thought this process reduced their ability to ask questions effectively. ${ }^{141}$ The main rationale for this procedure was to improve the quality of the experts' answers by allowing them to prepare adequately.

d. Experts' reactions. The experts' reactions to the discovery depositions ranged from puzzlement as to their necessity to indignation and even outrage at their intrusiveness. One panelist thought there was no need for depositions of any kind and that the report should be judged on its scientific merit. This expert asserted that "science was not served by this adversarial proceeding." Another panelist did not understand why discovery depositions, separate from trial depositions, were necessary. Not all experts had negative reactions to the depositions, however. One panelist was pleased with the discovery depositions and appreciated having a copy of the questions in advance. Two panelists found the requests for documents to be intrusive and generally inappropriate for a scientific inquiry. One expert believed that raw materials and notes should be kept so that others could replicate a study. Such notes and records are not public property, however, but the intellectual property of the scientist; thus, the notes should not have to be disclosed for cross-examination.

The panelists' reactions measure the gulf separating the scientific and legal spheres. One panelist, despite extensive briefing by special counsel before the discovery deposition, was shocked at the degree of disclosure required. Other panelists showed varying degrees of disagreement with fundamental principles of the legal system, such as access to discovery materials and rights to confront and cross-examine opposing viewpoints.

2. Motion to Disqualify a Panel Member and Discharge the Panel. Out of the discovery depositions arose a highly controversial challenge to the status of

138. See id. at 186-89, 368-69, 382-97.

139. See id. at 382-97.

140. See id. at 132-34, 396-97.

141. See supra note 37. 
a panel member and the panel itself, ${ }^{142}$ which generated national publicity. The evolution and resolution of this conflict contains important lessons for instructing experts on the limits of communication between appointed experts and the parties and the need to set clear standards for identifying conflicts of interests when scientific experts are recruited for court appointment.

During and shortly after the discovery depositions, plaintiffs' attorneys found that one of the expert panel members had solicited and received funds from one of the defendants to support a professional conference that was unrelated to silicone or breast implants. ${ }^{143}$ In the selection and screening process, that expert had disclosed a contribution of $\$ 5,000$ from one defendant but failed to disclose a contribution of $\$ 500$ from another defendant. ${ }^{144}$ Plaintiffs' investigation of this payment led to further depositions of the expert and a biostatistician who worked as part of the expert's team. ${ }^{145}$

In the additional discovery depositions, plaintiffs obtained more information about contacts between the expert and the defendant. ${ }^{146}$ None of these contacts related to silicone gel breast implants. ${ }^{147}$ Judge Pointer found that defendant's contacts were not intended to influence the expert's work and that the work was "impartial, unbiased, neutral, objective, and unaffected by any relationship or contact with the defendants." ${ }^{148}$

After the discovery depositions, and about a week before the videotaped trial depositions began, plaintiffs filed a motion to vacate the expert's appointment as well as the appointments of the other panel members and to withdraw the panel's report. ${ }^{149}$ Shortly after receiving the papers filed by the parties, Judge Pointer denied the motion orally on April 19, 1999, the day before videotaped depositions began. ${ }^{150}$

In a written ruling issued during the videotaped trial depositions-but before this expert was scheduled to testify-Judge Pointer explained his denial of plaintiffs' motion. He detailed the screening process used to identify conflicts of interest, clarifying three aspects:

(1) The screening form successfully elicited information about the expert's fundraising for the conference, and he had properly disclosed a $\$ 5,000$ payment; ${ }^{151}$

142. For a description of the context of that challenge, see Order No. 31L, Denying Plaintiffs' "Motion for Relief from Prejudicial Bias," Apr. 25, 1999, In re Silicone Gel Breast Implants Prods. Liab. Litig. (MDL 926), 793 F. Supp. 1098 (J.P.M.L. 1992) (No. CV92-P-10000-S) (visited Jan. 29, 2001)

$<$ http://earth. fjc.gov/BREIMLIT/ORDERS/order311.rtf $>$.

143. See id. at 1.

144. See id. at 4-5.

145. See id. at 1 .

146. See id. at 11-12.

147. See id.

148. Id. at 1 n.1.

149. See id. at 1 .

150. See id. at 2 .

151. See id. at 4-5. 
(2) the screening form directed the experts to report any changes or additions in his or her conflict-of-interest situation to a screening panel that was no longer functioning, ${ }^{152}$ and

(3) the question of whether the biostatistician working with the expert had any conflicts of interests was never examined. ${ }^{153}$

Plaintiffs argued that the expert should have reported the additional activity to the court. ${ }^{154}$ Judge Pointer ruled that this was unnecessary, especially because most of the communications occurred after the report had been issued publicly. ${ }^{155}$ Nevertheless, this incident highlights some effects of the absence of an explicit mechanism for addressing conflicts of interest that arise during the course of a lengthy appointment.

In initially restricting communications with defendants about breast implant matters, Judge Pointer intentionally did not limit communications with defendants regarding matters other than breast implants. Judge Pointer explained in his April 1999 ruling that his earlier choice "was deliberate," made "in recognition that the panelists' work on the Panel would be only one of their many professional activities, [and that] they should not be unnecessarily restricted by preventing them from routine contacts with pharmaceutical companies in performing activities unrelated to issues involved in breast implant litigation." Accordingly, the expert's belief that it was allowable to make such contacts "was both understandable and reasonable" and not a basis for disqualification. ${ }^{157}$

Judge Pointer's ruling framed an issue that is part of the larger debate about whether court-appointed experts should be used in adversarial litigation. Plaintiffs' attorneys argued that the shift of research funding from public to private sources has created subtle biases among researchers. ${ }^{158}$ Thus, the search for neutral, unbiased scientists is fruitless. Judge Pointer found that accepting this view "would, in essence, have precluded consideration of a substantial proportion of academicians, who were perhaps the persons most qualified to provide valid and reliable opinions." ${ }^{, 159}$

Prior to the expert's scheduled testimony, special counsel made an oral motion in limine to control the order of questioning so that issues related to the report would come first, and issues related to the conflict of interest allegations

152. See id. at $9-10$.

153. See id. at 6-8.

154. See id. at 9-10.

155. See id. at 11.

156. Id. at 6 .

157. Id.

158. See id. at 3 .

159. Id. Understandably, given the national and international publicity about the allegations of conflict of interest and bias, the court-appointed expert was quite upset. Special counsel representing the expert filed a motion in limine to prohibit plaintiffs from "exploring these meritless but inflammatory allegations of bias in their examination of" the expert. Special Counsel's Motion in Limine, Apr. 18, 1999, In re Silicone Gel Breast Implants Prods. Liab. Litig. (MDL 926), 793 F. Supp. 1098 (J.P.M.L. 1992) (No. CV92-P-10000-S). Judge Pointer denied the motion. 
would come later. ${ }^{160}$ Judge Pointer denied the requests in an oral ruling. ${ }^{161} \mathrm{He}$ found not that the matters alleged showed bias or lack of objectivity but that there was an arguable appearance of bias. ${ }^{162}$ Therefore, Rule 706 gave plaintiffs the right to cross-examine the expert ${ }^{163}$ which included the right to sequence the examination. As noted above, because Judge Pointer was presiding over multidistrict litigation, he had to worry that a restriction on cross-examination could result in a trial court finding the panel member's testimony to be inadmissible.

This incident yielded lessons that should guide future screening for conflicts of interest. At the least, a mechanism for disclosing and considering postappointment questions regarding potential conflicts of interest should be established. In addition, a mechanism is needed for screening and reviewing the qualifications of any colleagues working with the expert, because allegations of serious conflicts of interest concerning a significant contributor to an expert's report could contaminate the entire report. Without a mechanism for prior screening, no one would know whether a member of an expert's team was even a shareholder or grantee of a defendant.

Finally, this incident revealed the "cultural chasm" between scientific and legal approaches to questions of bias and conflicts of interest. Judge Pointer observed:

It appears that the approach of scientists is to critique research largely confined to the four corners of the reported research; "ad hominem" considerations directed at the individuals involved in that research generally are to be disregarded and may be viewed as inappropriate attacks upon the integrity of those individuals. On the other hand, the approach of those involved in litigation, at least in this country's adversarial system, tends to be one of skepticism and distrust, ready to consider possible motivations and influences that may have affected, even subconsciously, the conduct or conclusions of a study or, indeed, even the reported observations upon which the study is based.

This attitudinal difference, if the court is correct in its assessment, can produce some dysfunction when, as here, persons from the scientific community with little or no experience in litigation are co-opted into the legal system via court-appointment under Rule 706. This is a matter that deserves greater consideration and exploration as persons from both perspectives consider further use of Rule 706. Certainly this court, on reflection, sees that more detailed instructions as to what should and should not be permitted while a scientist serves as a court-appointed expert would have been desirable in bridging the gap. ${ }^{164}$

Judge Pointer's observations have implications for screening, instructing, and providing counsel for court-appointed experts. Because the ground rules are established by the legal system generally, and Rule 706 specifically, fairness demands that experts be fully informed of the risks and demands of the system

160. See Transcript of Video Deposition at 118-26, Apr. 26-27, 1999, Silicone Gel Breast Implants (No. CV92-P-10000-S).

161. See id. at 129-36.

162. See id. at 130-33.

163. See id.

164. Order No. 31L, Denying Plaintiffs' "Motion for Relief from Prejudicial Bias," Apr. 25, 1999, at 14, Silicone Gel Breast Implants (No. CV92-P-10000-S) (visited Jan. 29, 2001) <http://earth.fjc.gov/ BREIMLIT/ORDERS/order311.rtf $>$. 
before agreeing to serve. The panel members agree. Having observed this expert's experience, one expert panel member we interviewed would participate again only if the rules were clarified at the outset and special counsel were appointed earlier to frame the conditions of the appointment.

3. Trial Depositions. Trial depositions were held on eight consecutive days from April 20 to April 27, 1999, in Judge Pointer's courtroom in Birmingham, Alabama. ${ }^{165}$ Special counsel for the panelists conducted the direct examination, followed by cross-examination by a defendant's attorney, followed by crossexamination by a plaintiffs' attorney. Each panelist was permitted to be present while the other panelists were being examined.

All counsel were required to submit a list of specific topics of inquiry prior to the deposition, referring to specific parts of sections of books and articles. ${ }^{166}$ Topics involving "matters in which surprise is needed for effective impeachment" did not have to be submitted in advance. ${ }^{167}$ Plaintiffs listed an average of fifty topics for each of the four witnesses, covering the witness's qualifications, biases (including relationships with others who may be biased), methods of studying the issues, particular studies examined, and scientific issues relating to the final report. Topics included (1) "biases of [the witness], including prior relationships with industry"; (2) "appropriateness of a panel member accepting money or other benefits from a party and/or failing to disclose a benefit received"; and (3) "biases or weaknesses of the studies relied upon by [the witness] for her opinions." 168

Most of the testimony during the eight days of depositions focused on the technical details of the scientific standards and the studies on which the experts did and did not rely. ${ }^{169}$ On the whole, the testimony was complex and presented in scientific and technical terminology. Special counsel led each of the experts through his or her direct testimony. Each witness prepared slides, overheads, or blowups to outline major points. These presentations resembled lectures and were aimed at an intelligent, but not necessarily scientifically sophisticated, audience. The experts explained basic terms, the criteria for analysis, and supporting studies. ${ }^{170}$ Special counsel generally posed broad questions, launching the expert into a narrative lecture. Plaintiffs objected to the form of the testi-

165. See Order No. 31K, Protocol for Trial Perpetuation Depositions, Mar. 10, 1999, at 1, Silicone Gel Breast Implants (No. CV92-P-10000-S) (visited Jan. 29, 2001) <http://earth.fjc.gov/BREIMLIT/ ORDERS/order31k.rtf.>

166. See id. at 2.

167. Id.

168. Plaintiffs' List of Topic Areas and List of Documents for Trial Examination of Dr. Betty Diamond, Silicone Gel Breast Implants (No. CV92-P-10000-S) (on file with authors).

169. See, e.g., Transcripts of Video Depositions, Apr. 20-26, 1999, Silicone Gel Breast Implants (No. CV92-P-10000-S) (on file with authors).

170. See Transcript of Video Deposition of Dr. Nancy K. Kerkvliet, Apr. 24, 1999, Silicone Gel Breast Implants (No. CV92-P-10000-S) (on file with authors). 
mony; Judge Pointer overruled the objections subject to final rulings from trial court judges who may use the videotapes. ${ }^{171}$

a. Attorneys' reactions. Attorneys for plaintiffs and defendants found the procedures for the trial depositions to be fair. A couple of attorneys questioned the division of labor between special counsel and defendants' attorneys. There was considerable overlap because, in essence, both elicited direct testimony, explaining and supporting the experts' report. That overlap of roles, however, is due to the expert panel's uniform conclusions and its direct alignment with defendants' interests in the litigation. ${ }^{172}$ In other cases, it may be that an expert's report will not fully support one side or the other, and there will be a need for special counsel to give the experts an opportunity to present their report before the parties challenge it. Having special counsel conduct the direct examination seems necessary, given the barrier to ex parte communication that must be imposed on attorneys for the parties.

b. Experts' reactions. Two experts felt that the trial depositions focused less on the science issues than the discovery deposition had. Panel members appreciated the written questions for the discovery depositions and would have liked them for the trial depositions. The experts also had complaints about the videotaping process. Some were dissatisfied with the technical aspects of the videotaping, particularly the inability to display computerized graphics on the overhead projection machine. Another expert captured the general sense of the uncertainty about the usefulness of the videotapes: "I don't know about the videotapes, about how and whether they will be used. I see them sitting on a shelf. Who will use them? Who will edit them down to a useable size?"173

\section{VII}

\section{COST OF THE PANELS OF EXPERTS}

The costs associated with the use of technical advisors and court-appointed experts typically are charged to the parties. ${ }^{174}$ Because of the expected benefits of the panels' work in breast implant product liability cases throughout the nation, both Judge Jones and Judge Pointer sought partial payment of panel expenses from appropriations to the federal judiciary. ${ }^{175}$ The Judicial Conference

171. See id. at 148-49.

172. See supra text accompanying notes $96-98$.

173. See supra note 37.

174. For authority on the payment of court-appointed experts, see FED. R. EVID. 706(b). See also CECIL \& WILlgING, supra note 31, at 59-62 (noting that the flexibility of the rule permits the court to rely on the parties to compensate the expert).

175. See Judicial Conference of the U.S., AdMinistrative OfFice of The U.S. Courts, REPORTS OF THE PROCEEDINGS OF THE JUDICIAL CONFERENCE OF THE UNITED STATES 46 (1996) [hereinafter JUDICIAL CONFERENCE, REPORT OF THE PROCEEDINGS]. 
granted Judge Pointer's request but declined Judge Jones's. ${ }^{176}$ This section will discuss the costs of the two programs.

\section{A. Hall v. Baxter Healthcare Corp.}

Judge Jones wrote to officials in the judicial branch seeking federal funding of approximately $\$ 60,000$ for his panel's work, noting that the experts' reports would be useful in resolving the numerous silicone gel breast implant product liability cases pending in federal and state courts. ${ }^{177}$ In denying Judge Jones's requests for payment, the Committee on Court Administration and Case Management doubted that such benefits could be achieved in the context of local litigation and preferred that the expert panel perform its work as part of the multi-district litigation proceedings. ${ }^{178}$ The Committee feared that funding Judge Jones's panel would encourage the development of local panels in other cases that could duplicate or contradict the work of the national panel. ${ }^{179}$ Following the Committee's decision, Judge Jones asked the parties to pay the outstanding amounts owed to the advisors, which they reluctantly agreed to do. ${ }^{180}$ The parties paid approximately $\$ 76,000$ in fees and expenses for the four panel advisors and the special master. ${ }^{181}$

\section{B. In re Silicone Gel Breast Implant Products Liability Litigation}

In his request for federal funding, Judge Pointer noted that the panel's work would become part of the record in the 22,000 breast implant cases that had been consolidated in the multidistrict litigation process. ${ }^{182}$ A single report from a national panel of experts would provide a consistent foundation for decisions regarding the admissibility of evidence and contested factual issues. ${ }^{183}$ A single report could also save time and money spent on multiple independent expert panels in individual trials. ${ }^{184}$ Judge Pointer noted that funding by the federal judicial branch would show the court's "commitment to resolving difficult legalscientific questions in a manner that emphasizes 'truth' rather than partisanship or the parties' resources." ${ }^{, 185}$

The Judicial Conference approved the expenditure of $\$ 400,000$ to support the work of the panel, and barred the use of payments by the parties to supplement this amount. ${ }^{186}$ Two years later, with the work of the expert panel well un-

176. See Hall v. Baxter Healthcare Corp., 947 F. Supp. 1387, 1393 n.9 (D. Or. 1996) ("Although I requested funding for the Rule 104 experts, my request was denied.").

177. See Judicial Conference, Reports of the ProceEdings, supra note 175.

178. See id. at 46.

179. See supra note 37.

180. See id.

181. See Hall, 947 F. Supp. at 1393 n.9.

182. See Judicial CONFERENCE, Reports of the ProceEdings, supra note 175, at 46.

183. See supra note 37.

184. See Judicial Conference, Reports of the Proceedings, supra note 175.

185. See supra note 37.

186. See Judicial CONFEREnCE of the U.S., AdMinistrative OfFice OF THE U.S. Courts, SUMMARY OF THE REPORT OF THE JUDICIAL CONFERENCE COMMITTEE ON COURT 
derway, Judge Pointer requested, and was granted, an additional $\$ 400,000$ to support the panel's continued work. ${ }^{187}$ In his supplemental request, Judge Pointer noted unexpected difficulties encountered by the selection panel in identifying candidates suitable for appointment. ${ }^{188}$ The six selection panel members required extensive deliberations to agree on the best available scientists to fill the positions. ${ }^{189}$ Approximately half of the time was spent screening for conflicts of interest. ${ }^{190}$ Together, these factors increased the expense of the search beyond the expected amount. ${ }^{191}$ Moreover, the amount of material submitted by the parties for review by the science panel members greatly exceeded expectations. ${ }^{192}$ Some panel members conducted their own searches of scientific literature for additional material rather than rely completely on the parties' submissions. The Judicial Conference approved Judge Pointer's request for additional funds with the requirement that "the expenses be funded by the parties to the extent it was legal, feasible and consistent with prior representations to the parties." ${ }^{\prime 193}$ Even before receiving this qualification from the committee, Judge Pointer had imposed the cost of the special counsel and a number of consulting experts on the parties. ${ }^{194}$

The total cost of the national panel of experts, including fees and expenses, was $\$ 939,983.74 .^{195}$ Of that amount, the federal judiciary provided $\$ 733,645$ for selecting the experts and preparing the experts' report. ${ }^{196}$ The remaining $\$ 206,338.74$ reflects fees and expenses of the experts that arose during their depositions and testimony and was shared equally by the parties. ${ }^{197}$ The parties paid the cost of two special counsels to represent the panel members, which exceeded the total spent on the experts themselves. According to information provided by the administrator of the two court-administered funds established to support the work of the special counsels, fees and expenses relating to work

ADMINISTRATION AND CASE MANAGEMENT 29 (1998) (on file with authors) [hereinafter JUDICIAL CONFERENCE, SUMMARY OF THE REPORT].

187. See id.

188. See supra note 37.

189. See id.

190. See id.

191. The selection panel members were paid a total of $\$ 62,498$ for the time and expense required to identify and nominate the experts. The selection panel members were compensated at $\$ 200$ per hour. Although this was the same rate paid to the national science panel members, it was less than some of the selection panel members charged previously when appointed by the court as special masters or experts. Several panel members did not charge for all of the hours spent working on panel business, and one panel member declined to request payment, preferring to contribute her time to the project. See supra note 37.

192. The parties submitted over thirty-five linear feet of materials for review by the panel members. See supra note 37.

193. Judicial CONFERENCE, SUMmARy OF THE REPORT, supra note 186, at 29. The Judicial Conference also directed that specific expenditure controls be adopted for the remainder of the contract and that Judge Pointer seek reimbursement for the judiciary's expenses from any resulting mass class-action settlement. See id.

194. See supra note 37.

195. See id.

196. See id.

197. See id. 
by the two special counsels was at least $\$ 1,157,594.67 .^{198}$ The second special counsel, Ina Leonard, was appointed to represent the experts at depositions late in the process; her fees and expenses represent seven percent of the total amount. ${ }^{199}$

In our interviews, some attorneys from each side complained about the cost of the special counsel prior to the trial depositions. They raised specific questions about the need for special counsel to review the hundreds of scientific publications submitted to the panel by the parties. Both the attorneys and the experts complained that Mr. Kobayashi was often unavailable to respond to issues in a timely manner. Even defense attorneys "felt like [they] were at odds with Mr. Kobayashi." ${ }^{200}$ One believed that "the parties should not be placed in an adversarial role with special counsel. [The attorneys] were frustrated with the lack of information [they] received from him." ${ }^{201}$ In the future, the role of special counsel should be clarified at the outset, particularly with regard to the extent that counsel should become involved in the substance of the panel's work.

As one expert panel member commented, this initial effort at using an expert panel in the multidistrict litigation revealed ways to reduce costs. Suggestions included the use of rosters, setting clearer plans and goals for the panel's work, and clarifying the role of special counsel.

\section{VIII \\ PRELIMINARY ASSESSMENT OF WORK OF PANELS OF NEUTRAL EXPERTS}

The two programs examined in this report represent innovative extensions of the use of expert panels to respond to complex expert evidence. In Hall $v$. Baxter Healthcare Corp., the panel offered assistance to the court in ruling on the admissibility of scientific evidence. ${ }^{202}$ In In re Silicone Gel Breast Implants Products Liability Litigation, the panel offered a report and videotaped testimony intended to become part of the record in all cases returned to the district

198. Letter from Mr. Edgar C. Gentle III, Attorney-accountant appointed by Judge Pointer to administer the funds, to Mr. Thomas E. Willging 3, tbl. II (Dec. 20, 2000) (on file with authors). Mr. Gentle noted that this amount "[did] not include any of the disbursements made by the National Defendants directly to [special counsel] Mr. John Kobayashi." Id. at 1. Also, these costs did not reflect the fees and expenses of Mr. Kobayashi and his colleagues in preparing the videotapes and transcripts, a task that remains ongoing. See id. tbl. III. Mr. Kobayashi, the other attorneys, and the legal assistants were compensated at their customary hourly rate, up to a maximum of $\$ 200$ per hour. This cap is less than Mr. Kobayashi's usual hourly rate. See Order No. 31F, Appointment of Special Counsel to National Science Panel, Jan. 13, 1997, II 4, In re Silicone Gel Breast Implants Prods. Liab. Litig. (MDL 926), 793 F. Supp. 1098 (J.P.M.L. 1992) (No. CV92-P-10000-S) (visited Jan. 29, 2001) <http://earth. fjc.gov/BREIMLIT/ORDERS/order31f.rtf> .

199. See Letter from Mr. Edgar C. Gentle III, supra note 198, at 1-3, tbl. II (on file with authors). As of February 2001, editing of the National Science Panel video depositions continued. As of December 2000, the cost related to the editing totaled $\$ 164,945.25$. See id. tbl. III.

200. See supra note 37.

201. See id. Mr. Kobayashi declined our request for an interview. See FJC STUDY, supra note 15.

202. See Hall v. Baxter Healthcare Corp., 947 F. Supp. 1387, 1392 (D. Or. 1996). 
courts. $^{203}$ In each instance, the expert panels developed technical reports of extraordinarily high quality and presented findings consistent with those of recent independent science panels. ${ }^{204}$

It remains difficult, however, to specify the effects of the two expert panels. In Hall, Judge Jones stayed his summary judgment order, relying heavily on the work of the expert panel until he could consider the report prepared by Judge Pointer's panel. The cases before Judge Jones then settled and, consequently, Judge Jones's order was never reviewed on appeal. Judge Pointer regarded the report by his panel to be an intermediate product and the experts' videotaped testimony as final. ${ }^{205}$ Extensive settlement activity continued simultaneously with the panel's work, making it difficult to specify the impact of the panel and leaving few cases in which the videotaped testimony can be considered. This Part offers a preliminary assessment of the effect of the panel reports based on the impressions of the participants and citation of the reports in related litigation.

\section{A. Hall v. Baxter Healthcare Corp.}

We asked the participants whether the science issues were adequately addressed by the appointed experts and whether the proceedings achieved the courts' objectives. Judge Jones expressed general satisfaction with the process. Specifically, he indicated that the advisors aided his assessment of the conflicting scientific analyses offered by the parties. As a result of the hearing and Judge Jones's subsequent ruling dismissing plaintiffs' expert evidence on systemic injury claims, all cases subject to the hearing have settled. ${ }^{206}$

The technical advisors thought the process was beneficial in that it brought science to the courtroom and defined the boundaries of the causation debate. They expressed, though, that both more specific guidance and more time was needed to review the technical literature and prepare the report. Overall the advisors found their participation to be informative and beneficial.

Attorney comments varied. In general, defense attorneys, whose claims were furthered by the advisors' reports, were more pleased with the process. One defense attorney thought the process worked because the court and the parties focused on the question of scientific causation. Plaintiffs' attorneys, whose claims were weakened by the reports, were disappointed by the process. Several plaintiffs' attorneys, for example, thought Judge Jones's decision was in conflict with at least one advisor's findings that favored plaintiffs. One attorney suggested that a judge should not rely on inherent authority in appointing ex-

203. See Order No. 31, Appointment of Rule 706 Expert Witnesses at 1-2, In re Silicone Gel Breast Implants Prods. Liab. Litig. (MDL 926), 793 F. Supp. 1098 (J.P.M.L. 1992) (No. CV92-P-10000-S) (visited Jan. 29, 2001) <http://earth.fjc.gov/BREIMLIT/ORDERS/order31.rtf>.

204. See Review of the Reports of the Independent Review Group and the National Science Panel, in SAFETY OF SILICONE BREAST IMPLANTS, supra note 12, at 505-14 app. c.

205. As of February 2001, the editing of the videotaped testimony had not been completed.

206. Virtually all state court breast implant cases have settled, due in part to the joint hearing at which Judge Jones presided with a state court judge. 
perts. Similarly, another attorney suggested that the court's power to appoint technical advisors is defined explicitly in the Federal Rules of Evidence, together with procedural safeguards. Rule 706 contains clear and explicit, though perhaps incomplete, rules governing court-appointed experts, yet no similar procedural path is defined under Rule 104.

Since Judge Jones stayed his summary judgment order pending the release of Judge Pointer's National Science Panel's report, citations to Judge Jones's holding are rare. The opinion, however, has been cited for innovative use of panels of technical advisors ${ }^{207}$ development of authority for in limine proceedings, ${ }^{208}$ and its definition of "differential diagnosis."

\section{B. In re Silicone Gel Breast Implant Products Liability Litigation}

When we interviewed Judge Pointer in October 1999, he could not assess the process, because the videotaped depositions had not yet been introduced at trial. Judge Pointer did note, however, that the report appears to have had considerable impact on the dynamics of settlement negotiations. Although cases have settled at the same rate throughout the panel's tenure, the value of claims for systemic injuries has diminished. ${ }^{210}$ As a result of the national panel's report, systemic injury claims are no longer part of the process. Their absence has pushed down the dollar amounts of settlements. ${ }^{211}$ Of course, the total effect of the report and testimony by the panel will not be known until that testimony is presented at trial.

Overall, the expert panel members thought the court's objectives were met. $^{212}$ The experts reviewed the relevant scientific material, indicated areas of consensus within the material, and set the boundaries of the scientific debate. The experts, however, were not without complaints. One panel member was frustrated over not knowing how and whether the panel's report would be used as evidence at trial. Another thought it difficult to make immediate decisions based on complex, conflicting, and sometimes incomplete data.

207. See Association of Mexican-American Educators v. State of Cal., 231 F.3d 572, 610 (9th Cir. 2000) (Tashima, J., dissenting).

208. See Allison v. McGhan Med. Corp., 184 F.3d 1300, 1310 (11th Cir. 1999).

209. See Glastetter v. Novartis Pharm. Corp., 107 F. Supp. 2d 1015, 1019 (E.D. Mo. 2000).

210. Michael Green, a professor at the Wake Forest University School of Law, stated that "as a consequence of the report it will be hard to find a federal judge who will permit a case to be tried or who will sustain on post-trial motions a plaintiff's claims to systemic disease." Gina Kolata, Panel Can't Link Breast Implants to Any Diseases, N.Y. TIMES, Dec. 2, 1998, at A1.

211. "The mere anticipation of that court-appointed panel's report influenced the course of breast implant litigation. Plaintiffs reached a $\$ 3.2$ billion settlement with implant maker Dow Corning Corporation, driven in part by the pressure of the anticipated report." Erichson, supra note 1, at 1983. Defense attorneys familiar with the litigation opined that the mere pendency of the national panel's report helped to resolve breast implant cases with systemic claims before Judges Weinstein and Baer in New York. See Thorpe et al., supra note 1, at 34.

212. See Hulka et al., supra note 10, at $812-15$ ("We believe that such panels should be used more frequently, because they can bring unbiased information about complex scientific and medical issues into the courtroom."). 
Most panel members felt the entire process could have been completed in a year if they had had firmer deadlines. Delays in starting the review process, getting materials to the experts, appointing special counsel, and finding an efficient means of communicating among themselves extended the time required to prepare the reports. In general, it appears that the overall experience was satisfying, because all of the experts would consider serving as a court-appointed expert in the future, though perhaps under somewhat different conditions.

The views of attorneys in the MDL process appear to be affected by the extent to which their claims were furthered by the panel's report. Most plaintiffs' attorneys thought that the overall procedure failed to resolve properly the scientific issues and that expert panels should be reserved for narrower questions. One attorney thought the court's instructions were too vague and permitted ambiguous responses, suggesting that the instructions be drafted around the Daubert standards. Another attorney thought the panel members should have been treated as other trial witnesses and should have received no special protection from the court. Most plaintiffs' attorneys saw very little use in the panel's report and videotaped testimony. Due to the length of the process, most cases have settled. Moreover, the testimony will soon be outdated as new studies appear. ${ }^{213}$ Plaintiffs' attorneys felt that the "final product resulted from 'special' procedures that favored the defense. The process had no benefits for [our] clients, it was very expensive and time-consuming, but it was our only choice."214

In contrast, defendants' counsel thought use of the expert panel was a step toward ensuring that unreliable evidence would not be admitted. One attorney commented that the expert panel presented a more accurate picture than partyretained experts would have, especially in mass tort cases with high economic stakes. Another felt that the parties' experts were more candid when they spoke before peers on the panel at the hearing, resulting in admissions by parties' experts unusual to the discovery process.

Several defense attorneys were confident that the report and testimony will be useful in resolving questions about causation of systemic disease. They believe it has heightened attention to the scientific issues and will give judges more confidence to rule on science-based claims. One defense attorney cautioned against underestimating this "power of the [national p]anel's report to give nonscientist judges the courage and confidence to rule." ${ }^{215}$ They expect the panel's report will help build a consensus on these issues and minimize the inconsistent rulings among different courts. Another defense attorney commented that the major value of the report is its corroboration of defendants' experts' positions. Yet another thought the report had an impact on the Dow

213. See, e.g., Louise A. Brinton et al., Breast Cancer Following Augmentation Mammoplasty, 11 CANCER CAUSES \& CONTROL 819 (2000).

214. See supra note 37.

215. See id. 
Corning bankruptcy proceeding by setting the context in which those negotiations took place. ${ }^{216}$

The above assessment of the National Science Panel's impact may be affected by the release of the videotaped testimony, but the panel's report has so far been cited consistently with other reports in excluding expert testimony linking silicone gel breast implant with systemic disease or injury. ${ }^{217}$ Concerns that the panel's report would not be used consistently appear to have been unwarranted. ${ }^{218}$

IX

\section{SUGGESTIONS FOR USE OF PANELS OF NEUTRAL EXPERTS}

Using court-appointed experts is appropriate when the evidence is especially demanding and the opportunity for reasoned and principled consideration based on submissions by the parties has been exhausted or offers little promise. ${ }^{219}$ The difficulty of accommodating the conflicting values of science and law within such a process is unlikely to satisfy those who insist on the deliberate and open-ended consideration that is characteristic of science, or those who insist on the speedy and certain resolution of issues that is valued by law. ${ }^{220}$ Even in the best circumstances, such appointments should be invoked only after careful thought.

216. In In re Dow Corning Corp., the Panel's report was cited to demonstrate that "new" research negates the case that silicone gel causes some diseases alleged by breast-implant claimants. 244 B.R. 634, 655 (Bankr. E.D. Mich. 1999).

217. See Allison v. McGhan Med. Corp., 184 F.3d 1300, 1311 (11th Cir. 1999) (citing the Panel's report to illustrate the thoroughness of efforts to ascertain the reliability of the scientific evidence); Grant v. Bristol-Myers Squibb, 97 F. Supp. 2d 986, 989-90 (D. Ariz. 2000) (citing the Panel's conclusion that " [n]o association was evident between breast implants and any of the individual connective tissue diseases"'); Pozefsky v. Baxter Healthcare Corp., 194 F.R.D. 438, 440 (N.D.N.Y. 2000) ("In the absence of expert testimony concerning the causal link between the leakage of silicone from breast implants and autoimmune or corrective tissue disease, Plaintiff cannot establish a prima facie case.”); Bushore v. Dow Corning-Wright Corp., 1999 U.S. Dist. LEXIS 20697, at*9-15 (M.D. Fla. Nov. 15, 1999) (addressing the four Daubert factors and citing the Panel's report for its discussion of causation and its conclusion that the evidence does not currently support a scientific finding of causation).

218. Two law professors claim the report is not having the effect intended by Judge Pointer and others. They claim that early citation to the panel's results show "signs of conflict and redundancy" that will ultimately "jeopardize the utility of the Panel findings and, even more importantly, may discourage the future appointment of similar panels." Walker \& Monahan, supra note 10, at 817. As an illustration, they cite an unpublished case where a federal judge refused to allow the Panel's findings to be heard by a jury, which subsequently returned a verdict in direct conflict with the Panel's findings. See id. at 813 . This jury award was subsequently overturned by the trial judge, claiming that there was no scientifically valid basis for the jury verdict in the record. See D.C. Judge: \$10 Million Breast Implant Judgment Lacks Evidence, Reversed, MEALEY's LITIG. REP.: EMERGING DRUGS \& DEVICES, Oct. 5, 2000, at 15 .

219. See CECIL \& WILlgING, supra note 31 , at $88-89$.

220. As one expert panel member stated,

In science, it is not a failure to say "I don't know." One can think about the issue a bit longer and have time to think about how to respond. One can give a thoughtful answer, not the first one that comes to mind. The law's need for an immediate decision is inconsistent with science's interest in waiting for a correct answer.

See supra note 37. 
Despite the high quality of the information developed by the expert panels, interviews with the participants revealed a number of difficulties that are likely to arise in the future. In this part, we describe suggestions for judges to consider when appointing and using such panels. Most of these were either explicit suggestions of the participants or implicit in their comments.

First, the court should explore opportunities to develop the information necessary for thoughtful consideration of complex evidence without taking the extraordinary step of appointing experts. Expert panels are costly, timeconsuming, present difficult issues of administration, and raise concerns about the independence of judicial consideration. In the two cases presented here, the complexity of the evidence and the importance of establishing an accurate foundation for future litigation argued strongly for such extraordinary procedures. It should be noted that not all litigation will warrant four or five expert witnesses sitting as a panel. Many multidistrict litigations or individual cases or classes or consolidations require only one witness in a key discipline.

Second, the court should carefully consider the role that appointed experts will play in the litigation. The anticipated role of the expert will determine the legal authority that the court invokes to undertake the appointment. The court should generally articulate the questions it wants the experts to address at the beginning of the process. Doing so will help define whether technical advisors or court-appointed experts are needed, who they should be, what they should be asked to do, and how they should present their conclusions.

Appointing a panel of experts as technical advisors under the inherent authority of the court may be appropriate in the rare event that the judge requires direct advice from the expert panel. ${ }^{221}$ The judge must then decide what procedural protections are necessary to ensure that the parties' interests are not inadvertently compromised.

More frequently, expert panels will be appointed under Rule 706 and will be subject to its procedures. Potential experts must be clearly informed of the demands of the legal system when they consider the possibility of accepting the appointment. Experts appointed as witnesses must be informed that their testimony, not the preliminary written report, is the final product of their appointment. They must be told that, in addition to providing testimony, they may be deposed about the basis of their opinions and possible conflicts of interest.

Third, the court, with the parties' assistance, should determine which areas are needed to consider the evidentiary issues. Matching the skill of panel members with the needs of the litigation may be a difficult task, especially where the necessary skills represent narrow specialties or overlapping areas. In both cases, it proved difficult to find appropriate candidates willing to serve on the expert panels. The court may choose to seek assistance from professional or-

221. See Reilly v. United States, 863 F.2d 149, 154-55 n.4, 156 (1st Cir. 1988) (concluding that a district court has discretion to appoint a technical advisor, but it is expected that such appointments will be "hen's teeth rare," a "last" or "near-to-last" resort). 
ganizations to assist them in finding qualified and neutral experts. ${ }^{222}$ The judge must determine whether to seek experts who are experienced or inexperienced in the topic of the litigation. Potential experts who are aware of existing research in the disputed area or who have participated in studies will have a strong background in the issues but may also have preconceived notions inappropriate to the litigation. Experts unfamiliar with the disputed issues, on the other hand, will require additional time to become familiar with the issues.

Fourth, a court must screen the candidates for possible conflicts of interest. In both of these cases, direct and indirect ties to the corporate defendants made it difficult to find particular types of experts, such as toxicologists. Different conceptualizations in science and law of what constitutes a "conflict of interest" can result in misunderstandings. To avoid these problems, judges should consider using the screening questionnaire developed by the selection panel of special masters serving Judge Pointer. This questionnaire required written certification by the expert that no conflict existed as defined by the court. Parties should have an opportunity to review the credentials and background of those considered for appointment and to object to those they believe to be unqualified. Such participation should give the parties more confidence in both the expertise and neutrality of the candidate and should enhance the legitimacy of the appointment. The court should also establish a procedure for monitoring potential conflicts of interest arising during the litigation. For example, colleagues of panel members contacted for assistance on litigation issues must also be screened for conflicts of interest.

Fifth, the court should establish a procedure for organizing the panel's work. One possibility is to designate, or have the panel members select, one panel member as a convenor and administrative chair. This will permit easier coordination of tasks when the panel must work together as a group. This person can be the contact for communicating with the panel when it is necessary to exchange materials with the court or parties.

Sixth, shortly after appointing experts, the court should specify the duties and functions of the experts in a written order. This order should include the issues that the experts are asked to consider, the limitations and procedures for contact with persons outside the panel, including the judge, and the procedures that the panel should employ in presenting its information to the court. The extent of discovery and scope of depositions also should be established at the outset. To avoid problems with static instructions, a mechanism should be established permitting the court to expand and clarify the instructions as needed, with participation by the parties. Any substantive change in the instructions or procedures should be recorded as part of a written order and made available to the experts.

Seventh, the court should establish a budget with input from the experts and parties once the duties of the experts have been determined. Such a procedure

222. See Court Appointed Scientific Experts: A Demonstration Project of the AAAS, supra note 6; Registry of Independent Scientific and Technical Advisors, supra note 6. 
will help ensure that a realistic budget is maintained. In devising the budget, adequate administrative resources must be provided to support the panel's work.

Eighth, the court should maintain administrative oversight over the panel to ensure that it proceeds in a prompt and efficient manner. Such oversight may include establishing deadlines, or at least goals, for the panel's work, including the development of interim products. The court also may need to supervise an information exchange process in which the parties (1) summarize their arguments and proposed findings of fact for the appointed experts; (2) prioritize or rank all written materials submitted to the panel; and (3) respond to queries from panel members regarding the parties' proffer of expert evidence.

Ninth, a judge should consider appointing special counsel to represent inexperienced witnesses who will be deposed or cross-examined. The court should specify the role of special counsel in considerable detail, making clear which, if any, administrative duties will be undertaken by special counsel. A clear definition of this role will permit special counsel to speak with authority in areas designated by the court and avoid those activities in which there is no consensus regarding the involvement of special counsel.

\section{$\mathrm{X}$ \\ CONCLUSION}

These two programs represent innovative attempts to develop mechanisms to strengthen the ability of federal courts to consider challenging scientific evidence. Each program adapted existing rules and precedents to allow scientific experts appointed by the court to respond to a perceived need for additional analysis beyond that offered by the parties' experts. Each program strengthened the ability of the court to consider such information and to provide an informed assessment of the evidence. Each program also faced obstacles that future users might anticipate, and all participants found areas in which alternative approaches might have yielded better results. Numerous variations are possible, each framed to address the specific needs as they arise. The willingness of courts to explore such alternatives will become important as courts confront increasingly complex evidence. 


\title{
APPENDIX: CONFLICT AND BIAS SCREENING QUESTIONNAIRE
}

In re:

SILICONE GEL BREAST IMPLANT

PRODUCTS LIABILITY LITIGATION

(MDL-926)

\author{
Silicone Breast Implant Science Panel \\ Potential Sources of Bias and Conflict of Interest Questionnaire
}

\section{Instructions to Individuals Completing this Form}

Before you start to complete the questionnaire please review the list of corporate defendants on page five and read the "General Statement Concerning Bias and Conflict of Interest" on page two and "Instructions for Completing the Questionnaire" on page three.

Do not skip any questions. If you require clarification of any of the items on the questionnaire, contact Professor Alan Wolf of the Selection Panel for assistance."

When you have completed the questionnaire, sign and date the form and return it to Professor Wolf by fax or express mail.

Promptly report to the Selection Panel any changes or additions to the information reported on this form while you are either being considered for service on the Science Panel or while serving on the Panel.

\section{Contact Information}

Name: (Mr./Mrs./Ms./Prof./Dr.)

Telephone:

Fax:

Email:

Title:

Employer:

Address:

* Contact information for Professor Alan Wolf deleted. 


\section{General Statement Concerning Bias and Conflict of Interest}

The Silicone Breast Implant Science Panel (hereafter, the "Science Panel") will be charged with the responsibility of evaluating and critiquing pertinent scientific literature and studies bearing on issues of disease causation in the breast implant litigation. Since members of the Science Panel will be working directly for the court as neutral, independent experts, it is essential that panel members be free from any conflict of interest or significant bias as well as the appearance of such conflict or bias. This information is needed to ensure the integrity of the Science Panel. By screening potential members before they are selected, this questionnaire also safeguards panelists' professional and personal reputations by minimizing the possibility that embarrassing conflict or bias issues will arise in the courtroom.

"Bias" generally refers to views stated or positions taken that are largely intellectually motivated or that arise from the close identification or association of an individual with a particular point of view or the positions or perspectives of a particular group. For purposes of service on the Science Panel, the following are examples of potentially problematic forms of bias:

1. A panel member being placed in the position of reviewing his or her own work (or that of a family member, close friend, or colleague) for validity or scientific merit.

2. A panel member being committed to a fixed position on a particular issue through public statements (e.g., testimony, speeches, interviews, lectures, etc.), publication (e.g., articles, books, etc.), close identification or association with the positions or perspectives of a particular group, or through other personal or professional activities.

Certain forms of bias may be more properly characterized as conflicts of interest-e.g., where the individual is a senior officer of a professional society that espouses a fixed position on the issue.

"Conflict of Interest" means any financial or other interest which conflicts with the service of an individual because it could either impair the individual's objectivity or create an unfair competitive advantage for any person or organization. A conflict is likely to be present where the efforts of the Science Panel may result in a direct or indirect economic benefit or loss to particular individuals or groups. Illustrative examples of direct economic benefit include:

1. A panel member (or member of his or her immediate household) has a significant financial investment or other close tie to a corporate defendant. (Highly diversified mutual funds investing in one or more corporate defendants do not constitute a significant investment.)

2. A panel member has a family member or close friend who is a party to the action, or who is otherwise involved in the litigation (e.g., a family member who is an attorney involved in the litigation). 
Examples of indirect economic benefit include:

1. A panel member is a junior faculty member whose department chair (or other senior faculty) has taken a fixed position regarding the merits of this litigation.

2. For purposes of critically reviewing the relevant scientific literature, a panel member requests that another scientist furnish him or her with the raw data underlying a published work. Rather than using the data solely for the purposes of serving the court, the panel member envisions using the data for his or her own subsequent research efforts. (In such a case the panel member should contact all relevant parties for permission to use the data.)

The examples above are illustrative, but not all-inclusive. If you have any question as to the existence or appearance of bias or conflicts, please bring these matters to the attention of the Selection Panel.

\section{Instructions for Completing the Questionnaire}

Please note that the following questions refer variously to "you," "you or any members of your household," or, most broadly to "you, members of your household or members of your department."

Any reference to an "interested party" refers to:

1. plaintiffs and defendants in the current litigation

2. individuals or organizations that are otherwise substantially involved in the current litigation (e.g., law firms)

3. individuals or organizations that otherwise have a stake in the outcome of the litigation (e.g., "educational" organizations funded primarily by a party or medical societies)

4. potential litigants (e.g., close friends or relatives who have implants, and are therefore potential plaintiffs).

Your responses to the following questions should be typed on additional sheets of paper, rather than on this form.

Please provide all relevant details for any questions answered in the affirmative. An affirmative response to one or more questions does not automatically disqualify you from serving on the panel. Further explanations may, however, be requested.

If the answer to a question is contained in your curriculum vitae you may simply refer to and attach the appropriate pages from it.

\section{Personal interests}

1. Are you or any members of your household interested parties?

2. Do you have close friends or family members who are plaintiffs in these actions, attorneys involved in this litigation, or are employed by defendant corporations? 


\section{Financial interests}

3. Have you or members of your household ever worked for any interested party to the silicone breast implant litigation? (This includes both work relating to the implant litigation and any other type of work.)

4. Have you or members of your household ever received any research funds, graduate support, or any other funds (awards, honoraria, speaking or consulting fees, etc.) from any interested party?

5. Do you or members of your household currently have significant investments in any of the defendant corporations in the form of stocks, bonds, etc.? (You need not report highly diversified mutual funds or similar investment vehicles.) Do you or members of your household currently have investments in corporations which, although not parties to the litigation, have a stake in its outcome?

6. Have you, members of your household, or members of your department conducted any research in the area of disease causation due to silicone breast implants? Was this research funded? If so, by whom? Did this research result in publication? If so, give citations.

7. Have you or members of your household conducted any research which was funded by corporations which, although not parties to the silicone implant litigation, have a stake in its outcome (e.g., pharmaceutical corporations that use silicone in medical devices)? Have you or members of your household served as consultants to such companies on any matter?

\section{Public statement and positions}

8. Have you, members of your household, or members of your department made any public pronouncements (e.g., to the press, to a class, or at a professional meeting) regarding: any aspect of the silicone breast implant litigation; the conduct of the parties to the litigation; your conclusions as to the relationship between breast implants and any of the medical conditions (e.g., systemic lupus, erythematosus, rheumatoid arthritis, scleroderma, polymyalgia) that plaintiffs complain of?

9. Do you have any colleagues ${ }^{* *}$ at your institution or others, or a close friend at any institution, who has conducted research in the area of diseases allegedly caused by silicone breast implants? Have you ever shared a grant with these individuals? Have you ever co-authored any research publication with these individuals?

10. Have you or members of your household ever been contacted by anyone (e.g., parties, the press, lawyers) as regards silicone breast implants or the related litigation? What was the extent of this contact?

11. Have you ever reviewed a grant proposal or a journal article relating to diseases that might be caused by silicone breast implants?

\section{Previous Litigation Experience}

12. Have you ever served as an expert witness? If so, who were the parties to the action? For whom did you work? What was the nature of your involvement in that litigation? (e.g., did you prepare reports? testify? were you deposed?)

\section{Additional information}

13. Please report any service (full-time or part-time) with federal, state, or local government that may be related to the silicone breast implant litigation. Also include any other consulting or advisory work with professional organizations,

** For purposes of this question, a colleague is a person with whom you have a significant interaction in research, teaching or administration. 
trade associations, public interest groups, or civic groups that may be related to the litigation.

14. Is there any other connection between you and any interested party-or any other factor-that might impair your ability to serve on the Science Panel that has not been addressed by any of the above questions? Are there factors that others might reasonably construe as creating such impairments?

I have read the "General Statement Concerning Bias and Conflict of Interest" and the "Instructions for Completing the Questionnaire" and have answered the above questions in light of those statements, completely and to the best of my ability. I know of no reason why I cannot serve the Court as a neutral, unbiased, and independent expert. 